\title{
ARENITOS DA FORMAÇÃO BAURU: ESTUDO DE ÁREAS-FONTE
}

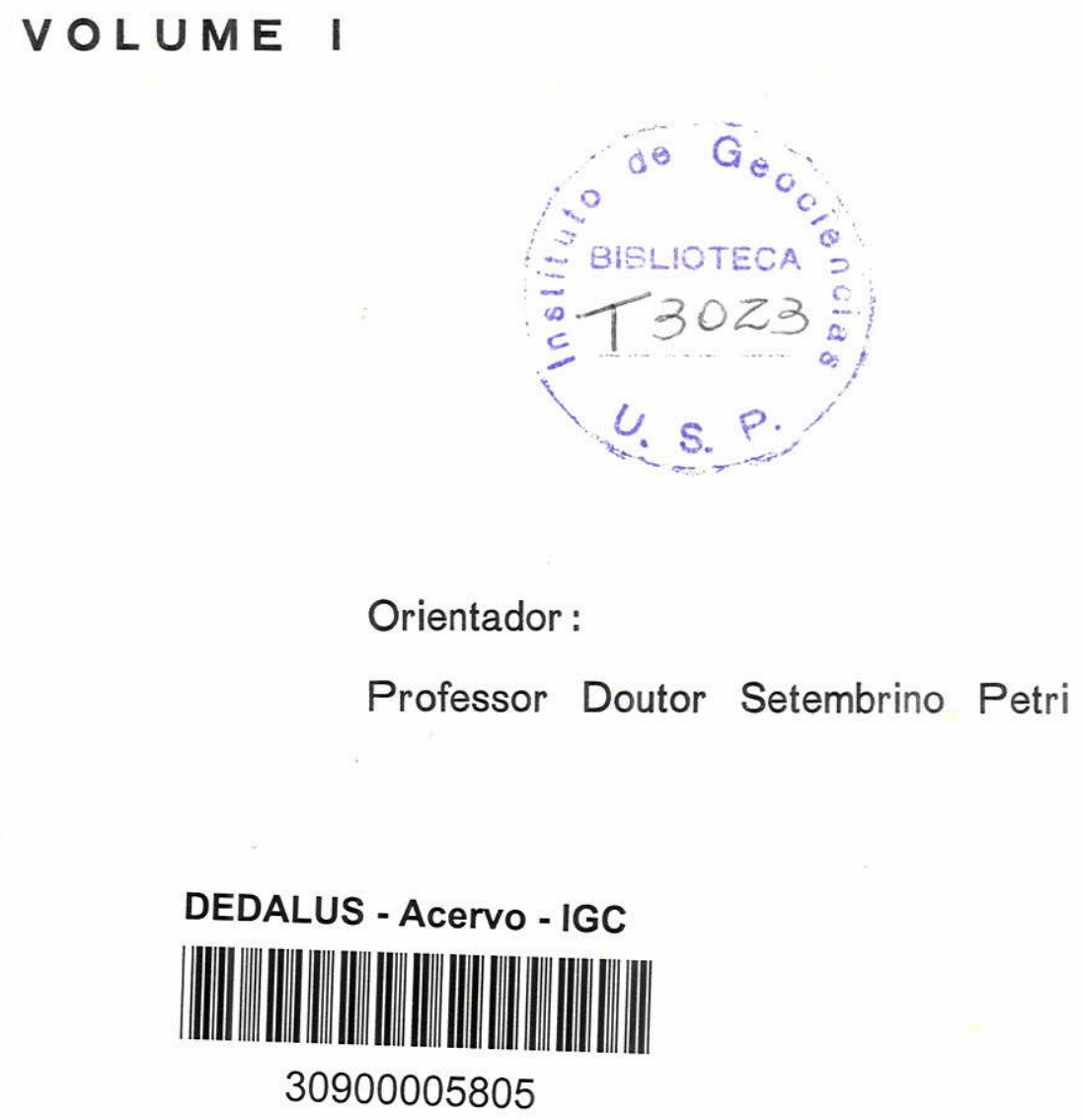

Orientador :

Professor Doutor Setembrino Petri

DEDALUS - Acervo - IGC

30900005805

SÃO PAULO

1976 


\section{VOLUME I}

RESUMO

2.1 .2 - Cálculo dos parâmetros estatísticos das distribuições

2.1.2.1 - Distribuição total

2.1.2.2 - Distribuição areia

2.2 - APRESENTAÇÃO DOS RESULTADOS

2.2.1 - Parâmetros estatísticos das dis tribuições

2.2.2 - Nümero de classes texturais

2.3 - ANÁLISE DOS RESULTADOS

2.3.1 - Análise de frequência dos parâmetros estatisticos da distribuição total

2.3.1.1 - Diāmetro mëdio 
2.3.2 - Anālise de frequência dos parâmetros estatisticos da distribuição areia

2.3.2.1 - Diâmetro médio

2.3.2.2 - Desvio padrão

2.3.2.3 - Assimetria

2.3.2.4 - Curtose

2.3.3 - Anālise de frequência do número de classes texturais

TEOR DE CARBONATO DE CÁLCTO

3.1 - METOdOLOGIA E LIMITAÇÕES

MINERAIS PESADOS

4.1 - METODOLOGIA

4.2 - FEIÇÕES PRINCIPAIS DOS MINERAIS PESADOS TRANSPARENTES NÃO MICĀCEOS DA FORMAÇÃO
BAURU

4.3 - ANÁLISE DE FREQUENCIA DOS MINERAIS PESA DOS NÃO MICACCEOS

4.3 .1 - Frequência média

4.3.2 - Frequência de ocorrēncia

4.4 - INDICES DE MATURIDADE MINERALÓGICA 
4.5 - PROVĀVEIS ÁREAS-FONTE DA FORMAÇÃO BAURU

4.6 - MATURIDADE MINERALŌGICA

4.7 - DISSOLUÇÃO INTRA-ESTRATAL 31

4.8 - NÜMERO DE ESPËCIES MINERALÓGICAS. 32

ANALLISE DE SUPERFICIE DE TENDENCIA

5.1 - INTRODUÇÃO

5.1.1 - Parâmetros granulométricos

5.1 .2 - Minerais pesados

5.1 .2 .1 - Frequência relativa dos minerais

5.1 .2 .2 - fndices de maturidade mineralógica

5.2 - SUPERFICIES DE TENDÊNCIA DAS FREQUÊNCIAS DE MINERAIS PESADOS

5.2 .1 - Cianita

5.2 .2 - Turmalina

5.2 .3 - Granada

5.2 .4 - Epidoto

5.2 .5 - Estaurolita

5.2 .6 - Rutilo

5.3 - SUPERFICIES DE TENDÊNCIA DOS INDICES DE MA TURIDADE MINERALÖGICA DA FORMAÇÃO BAURU

5.4 - SUPERFICIES DE TENDENCIA DOS PARAMETROS GRA NULOMÉTRICOS DA FORMAÇÃO BAURU 
CARACTERIZAÇĀO SEDIMENTOLOGICA DAS FACIES DA FORMAÇĀO BAURU

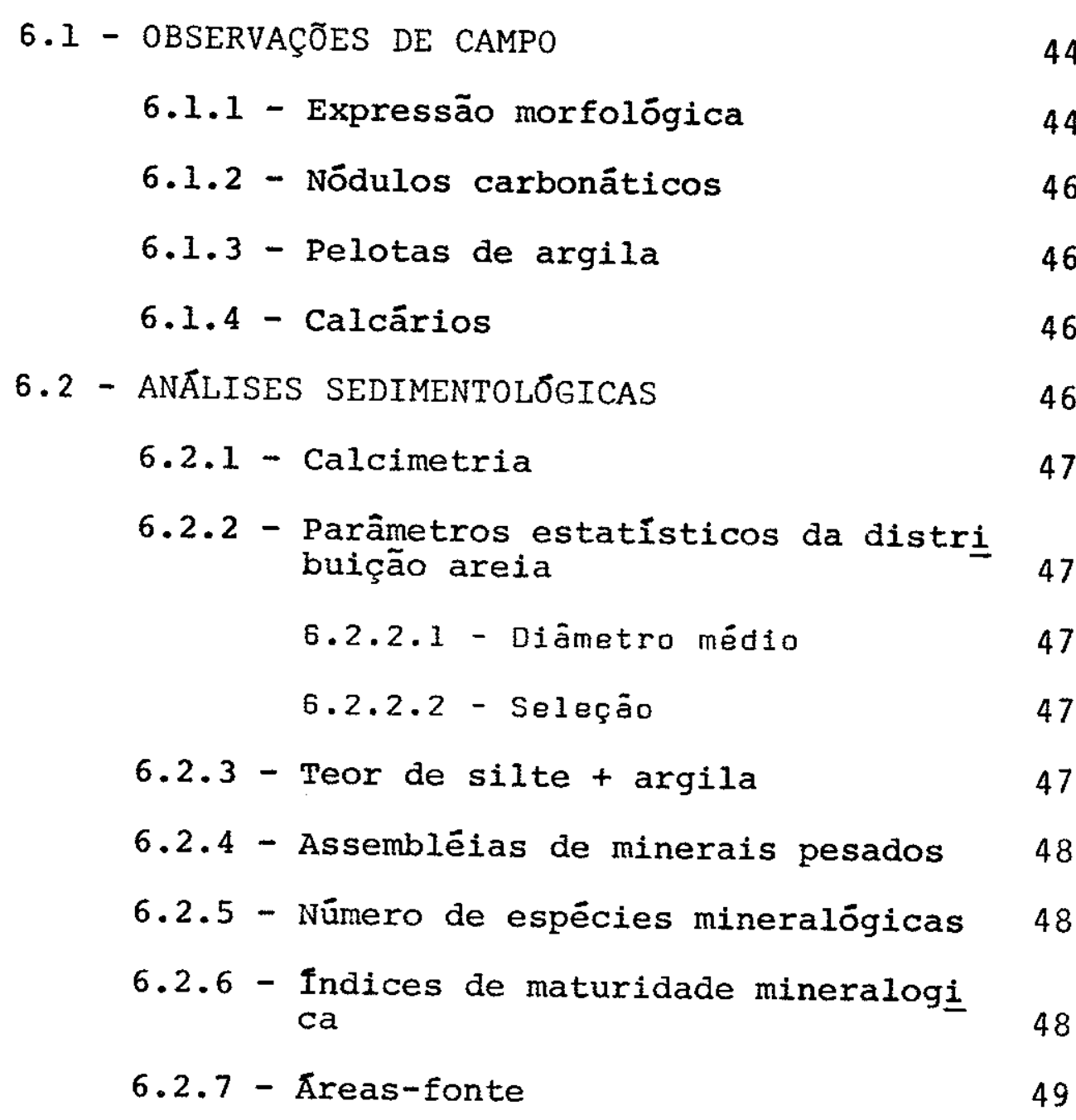

CAPITULO 7

ESTRATIGRAFIA DA FORMAÇÃO BAURU

7.1 - TRABALHOS PREVIOS 
VOLUME II

ANEXOS

ANEXO I - ESTAMPAS

ANEXO II - PERFIS E FIGURAS

ANEXO III - TABELAS 
RESUMO

No presente trabalho foram realizadas observações de campo e exames sedimentolögicos: minerais pesados, granulome tria e calcimetria, com o intuito de caracterizar os sedimentos da Formação Bauru e auferir idēias relativas a sua gênese.

Em vista da pequena densidade de observações o traba Tho é necessariamente preliminar, mas acreditamos que os resul tados obtidos sejam suficientes para a caracterização de três fácies na Formação Bauru.

Embora trate principalmente de estudo de proveniên cias, o trabalho fornece dados sedimentológicos que auxiliam na elaboração de critērios de correlação estratigräfica e no escla recimento de problemas tectōnicos e sedimentológicos ligados $\bar{a}$ Formação Bauru.

A aplicação de anālise de tendência aos dados de mine rais pesados e de granulometria permitiram a caracterização de āreas-fonte, dando esclarecimentos a respeito da paleogeografia.

$\mathrm{Na}$ interpretação dos dados obtidos em minerais pesa dos, não foram levados em conta os resultados publicados em tra balhos anteriores, pois estes não descrevem a metodologia empre gada, a responsāvel provavelmente pela baixa reprodutibilidade notada neste trabalho. Acrescente-se, entretanto,que a ārea de amostragem deste trabalho engloba as āreas dos trabalhos prē vios. 
CAPITULO I

INTRODUÇAO

1.1 - OBJETIVOS E AREA DE ESTUDO

Atravēs do estudo integrado de diferentes critērios se dimentolögicos procuramos caracterizar as äreas-fonte dos aren $\underline{i}$ tos da Formação Bauru, inferindo ainda idéias sobre a paleogeo grafia.

Para o presente trabalho foram coletadas amostras prin cipalmente no Estado de São Paulo e Triāngulo Mineiro. A Figu ra 1 mostra o mapa geológico com a localização das amostras.

1.2 - AMOSTRAGEM

Os trabalhos de campo compreenderam o conhecimento pré vio do autor, oriundo de vārios levantamentos executados na Bä cia do Paraná, e viagens efetuadas para este trabalho. As viá gens compreendendo coletas de amostras superficiais, observações geológicas gerais e descrição de testemunhos de dois poços de sondagem, consumiram vinte dias de campo. Foram em número de quatro, sendo duas para coleta de amostras superficiais e duas para descrição e amostragem dos poços.

A amostragem teve como finalidade obter materiais para estudos de granulometria, calcimetria, e principalmente de mine rais pesados.

Houve intenção de caracterizar tanto as variações geo gräficas quanto as variações estratigräficas.

Procurou-se dentro do possivel (existência de bons 
afloramentos, existência de estradas, etc...) coletar amostras mais ou menos espaçadas, para que toda a ärea fosse uniformemen te abrangida evitando-se assim a concentração local de amostrá gem.

Geograficamente estas amostras pontuais provêm dos E tados de São Paulo, Minas Gerais, Goiās e Mato Grosso, e estrá tigraficamente fazem parte de vārios nỉveis dentro da Formação Bauru.

Foram usadas neste trabalho trinta e nove amostras su perficiais do trabalho de suguIo (1973b), amostras estas denomi nadas aqui de KS.

As amostras $\underline{P B}$ (setenta e duas amostras) correspondem às amostras superficiais coletadas especificamente para este tra balho.

Para o estudo de variações estratigräficas foram usa das amostras de dois poços de sondagem, coletadas de $10 \mathrm{em} 10 \mathrm{~m}$.

As amostras Al (vinte amostras) correspondem as amos tras de testemunhos de sondagem do poço de Alvinlāndia (SP).

As amostras GS (dezesseis amostras) correspondem às amostras de testemunhos de sondagem do poço de General Salgado $(S P)$.

Ao todo foram usadas neste trabalho cento e quarenta e sete amostras, sendo cento e onze amostras superficiais e trinta e seis amostras de testemunhos de sondagem.

Na Tabela I, consta uma relação das amostras superfi ciais de sedimentos da Formação Bauru com especificaçoes de pró cedéncia, descrição litológica sucinta, e os processamentos aos quais foram submetidas as amostras.

As amostras de testemunhos aparecem localizadas nas descrições dos poços de sondagem (Perfis 1 e 2). 


\section{ANALISES GRANULOMETRICAS}

2.1 - METODOLOGIA

\subsection{1 - Granulometria}

Inicialmente foi feito um quarteamento das amostras pa ra se chegar a porções de pesos adequados, conforme a litologia, sendo estes, cerca de 100 gramas no caso de arenitos mais puros e 50 gramas nos de arenitos muito argilosos.

As amostras foram a seguir desagregadas manualmente ou com a ajuda de um martelo de borracha. As amostras que apresen tavam cimento carbonätico e difícil desagregação, foram atacadas com ácido clorídrico a $30 \%$ e posteriormente lavadas com à gua quente para lixiviar ao mäximo o $\mathrm{HCl}$, tendo sido evitado o uso de bases para neutralização do meio.

Apōs o quarteamento e desagregação, as amostras foram colocadas em suspensão e homogeneizadas por meio de agitador ro tativo. Para evitar o problema da floculação foi utilizado o pí rofosfato de sōdio como defloculante.

As amostras foram processadas por pipetagem seguida de peneiramento. A pipetagem foi utilizada para dimensionamento de particulas entre 0,062 e $0,004 \mathrm{~mm}$ de diametro e o peneiramento para particulas entre 4,0 e $0,062 \mathrm{~mm}$. A escala granulométrica usada foi a de Wentworth (1922 in SUGUIO, 1973a), sendo que no peneiramento foram intercaladas peneiras de 2,$83 ; 1,41 ; 0,707$; 0,$354 ; 0,177$ e $0,088 \mathrm{~mm}$. 
2.1.2 - Câlculo dos parâmetros estatisticos das distrí buições

\begin{abstract}
Nos cālculos dos parâmetros foram usadas as fórmulas propostas por FOLK \& WARD (1957 in SUGUI0, 1973a). Os cālculos foram efetuados no computador Burroughs B6600/B7700 do Centro de Computação Eletrōnica da Universidade de São Paulo, a partir de um programa denominado LABSE, em linguagem FORTRAN IV, desen volvido por Jorge Kazuo Yamamoto, estagiārio do Laboratōrio de Sedimentologia do Instituto de Geociēncias da U.S.P. Neste pro grama são usados como dados, o peso inicial da amostra e os pe sos de cada fração granulométrica. São obtidas as porcentagens de cada classe granulomëtrica, porcentagens acumuladas e os parā metros estatisticos para distribuição total e para a distribui ção areia.
\end{abstract}

\title{
2.1.2.1 - Distribuição total
}

Foram calculados os parāmetros estatisticos da distri buição total, considerando os intervalos de areia, silte e argi la.

As anālises de distribuição total apresentaram os se guintes problemas:

- Muitas partículas de diāmetro entre silte e argila podem provir de alterações de feldspatos (intemperismo), não di retamente ligadas à sedimentação da rocha.

- A prōpria metodologia de peneiramento e pipetagem im plica problemas de anālise indireta. E o intervalo argila $\bar{e}$ de discriminação quase impossivel, tendo sido apenas calculados os teores de particulas menores que $0,004 \mathrm{~mm}$.

- A pipetagem apresenta ainda o problema da Lei de Stokes, vāilida apenas para partículas teoricamente esféricas 
de mesma densidade, num meio de viscosidade homogenea (no caso o meio considerado foi a àgua). Na realidade, as partículas não são esféricas, possivelmente apresentam densidades diferentes e a viscosidade do meio varia de acordo com a concentração de par tĩculas e micelas em suspensão e solução.

- No caso de amostras ümidas foram retiradas porções de 10 gramas para secagem na estufa. A partir da diferença en tre o peso inicial e final foi calculada a umidade de cada amos tra, descontada do peso inicial das amostras submetidas ao pene $\underline{i}$ ramento e pipetagem. Este cālculo de teor em àgua das amostrás tambēm implica em anālise indireta.

- As amostras que apresentaram muito cimento carbonā tico foram de inicio atacadas com àcido clorídrico. Nestes ca sos, e por mais completa que tenha sido a lavagem posterior com ägua quente, sempre permanece certa acidez na suspensão final, 0 que provoca floculação das partículas, mesmo com o uso do deflo culante (pirofosfato de sōdio). Foi evitado o uso de bases para neutralização do meio, pois a adição de bases em meio àcido pro vocaria a formação de sais.

2.1.2.2 - Distribuição areia

Foram calculados os parāmetros estatisticos consideran do apenas a distribuição no intervalo areia, eliminando os inter valos silte e argila.

2.2 - APRESENTAÇÃO DOS RESUltAdOS (TABELA II)

2.2.1 - Parâmetros estatísticos das distribuições

Os parâmetros utilizados foram: diāmetro mēdio, desvio padrão (seleção), assimetria e curtose, conforme förmulas propos 
tas por FOLK \& WARD (1957 in SUGUIO, 1973a).

2.2.2 - Nümero de classes texturais (conforme escala de Wentworth)

A Tabela III, alēm dos resultados do nümero de classes texturais, apresenta os resultados porcentuais de teores de $\mathrm{CaCO}_{3}$, silte + argila, argila e areia; e resultados da relação entre clāsticos grossos (areia) sobre clästicos fines (silte+ argila). Estes resultados serão analisados nos Capitulos $V$ e VI.

2.3 - ANÁLISE DOS RESULtados

2.3.I - Anālise de frequência dos parâmetros estatís ticos da distribuição total (Tabela IV)

A Formação Bauru de uma maneira geral se apresenta li tologicamente homogénea. E caracterizada, como pode ser observa do na Tabela IV, por litologia de arenitos finos e muito finos, argilosos e/ou carbonáticos, seleção pobre a muito pobre, com assimetria variando de muito positiva a positiva e finalmente, cur tose muito leptocürtica a leptocūrtica.

2.3.1.1 - Diâmetro médio

Reflete grande homogeneidade litológica, $81 \%$ das amos tras analisadas apresentam diāmetro médio enquadrados entre areia fina e muito fina. 
Os valores em $86 \%$ das amostras estudadas variam de pobremente a muito pobremente sefecionados.

2.3.1.3 - Assimetria

Entre as amostras estudadas $96 \%$ apresentam uma assime tria variando de positiva a muito positiva, indicando uma pior
seleção para o lado dos clásticos finos.

2.3 .1 .4 - Curtose

Entre as amostras estudadas $82 \%$ apresentam-se com cur vas variando de leptocūrticas a muito leptocūrticas.

2.3.2 - Análise de frequência dos parâmetros estatís ticos da distribuição areia (Tabela V)

Analisando apenas o intervalo areia $(2,0$ a $0,062 \mathrm{~mm})$ das amostras da Formação Bauru, verificamos pela Tabela $V$, que as amostras se apresentam com diāmetro mëdio variando de areia fi na a muito fina, com seleção variando de moderadamente a bem se lecionada, com assimetria variando de aproximadamente simétrica a negativa, com curtose variando de mesocūrtica a platicürtica.

o fato das amostras apresentarem na distribuição total, seleção variando de pobremente a muito pobremente selecionada e - intervalo areia das amostras se apresentar moderadamente a bem selecionado, sugere para a Formação Bauru uma origem parcial de 
sedimentos preexistentes.

2.3.2.1 - Diâmetro médio

Como afirmado anteriormente, em virtude da grande homo geneidade 1 itolögica, $86 \%$ das amostras apresentam diāmetro médio do intervalo areia variando de areia fina a muito fina.

2.3 .2 .2 - Seleção (desvio padrão)

Os valores de seleção em $96 \%$ das amostras apresentam - intervalo areia variando de moderadamente a bem selecionado,evi denciando uma grande homogeneidade.

2.3.2.3 - Assimetria

0 intervalo areia de $74 \%$ das amostras estudadas apre senta-se com curvas aproximadamente simētricas e com assimetria negativa, com pior seleção para as classes de areia mais grossa.

$2.3 .2 .4-$ Curtose

Entre as amostras estudadas $87 \%$ apresentam curvas va riando de mesocürticas a platicúrticas, confirmando a grande hó mogeneidade litolögica. 
2.3.3 - Anālișe de frequência do número de classes tex turais

A Tabela VI evidencia que as amostras da Formação Bau ru são extremamente homogēneas quanto ao nümero de classes tex turais; $76 \%$ das amostras apresentam de nove a dez classes textu rais (escala de Wentworth). 
CAPITULO 3

TEOR DE CARBONATO DE CÃLCIO

o carbonato de cálcio nos arenitos ocorre sob a forma de cimento preenchendo os espaços entre os grãos de quartzo, as sociado à matriz argilosa, ou ainda, formando nödulos.

são comuns, nos resĩduos pesados das amostras não ata cadas por ācido, augitas com bordas substituidas por carbonatos, provenientes de alteraçōes intra-estratais (Estampa 4, Fotomicro grafias $C$ e D).

Acreditamos na natureza essencialmente autígena dos carbonatos, jā que os grãos de carbonato encontrados não mostram feições clästicas. Os grãos são provenientes de alterações in tra-estratais de augitas e da desagregação de nōdulos.

Segundo SUGUIO (1973b) "Embora tenham sido verificados em alguns locais (ärea de Ponte Alta, MG) fragmentos de tamanho de seixos, constituídos de calcários, incluídos em camadas areno sas superpostas a leitos calcārios, particulas arenosas ou sî ticas com esta composição não puderam ser constatadas. Este fá to parece denotar a sua natureza essencialmente quimica, jă que os fragmentos maiores encontrados foram derivados do retrabalha mento local de camadas calcārias recém-depositadas, mas partīcú las menores se fossem encontradas poderiam indicar transporte por distāncias mais longas".

\section{1 - METODOLOGIA E LIMITAÇÕES}

Foi retirada uma porção de 10 gramas de cada amostra estudada. Esta porção apōs triturada, foi atacada com äcido clorĩdrico a $30 \%$ a quente, atē o ponto de desaparecimento de qualquer efervescéncia. A porcentagem de carbonato foi calcula 
da a partir da diferença do peso inicial e do peso final do mate rial seco.

A anālise dos resultados de teores de carbonato de cā cio apresenta as seguintes limitações:

- A amostragem superficial foi em parte seletiva, pois foram amostrados os afloramentos mais frescos, que são de areni tos mais ricos em nōdulos carbonāticos (mais resistentes ao in temperismo e erosão).

- O fato de algumas amostras se apresentarem um pouco intemperizadas. Segundo SUGUIo (1973b) "Em se tratando de cimen to relativamente solüvel nas condições normais de intemperismo, por äguas meteöricas, as rochas arenosas intensamente alteradas são quase sempre isentas de cimento carbonātico".

PIERUCETI \& BRANDT NETO (1974) estudando variações de teor de $\mathrm{CaCO}_{3}$ em poços de sondagem da Formação Bauru, na cidade de São Josē do Rio Preto, verificaram que amostras situadas aci ma do nível hidrostātico, embora não evidenciassem alterações in tempéricas, apresentaram teores de carbonato menores, devido a possivel lixiviação.

- Nos niveis em que o carbonato aparece como cimento, - arenito é homogeneamente carbonātico. Por outro lado, os ni veis onde o carbonato $\bar{e}$ nodular, a rocha è muito heterogēnea, pois se em algumas partes se observa riqueza de nōdulos, em ou tras, o carbonato nem como cimento comparece.

\section{2 - INTERPRETAÇÃO DOS RESULTADOS}

A Tabela III mostra os teores de carbonato de cālcjo das amostras estudadas.

os resultados de ataque químico indicam que os teores de carbonatos como cimento na Formação Bauru apresentam valores sempre inferiores a $10 \%$. As amostras que apresentaram valores muito altos de $\mathrm{CaCO}_{3}$, se referem a arenitos com carbonato nodu 
lar. Algumas amostras totais GS e AL apresentaram valores da or dem de 20 a $30 \%$ de $\mathrm{CaCO}_{3}$, que caīram para menos de $10 \%$ com a re tirada dos nōdulos.

Não parece existir uma variação sistemätica de teores de carbonato de cālcio nos poços de Alvinländia e General Salga do. Ao longo dos perfis dos poços de sondagem, notamos a exis tência de níveis onde o carbonato aparece como cimento e niveis onde o carbonato aparece na forma de nódulos.

Segundo PIERUCETI \& BRANDT NETO (1974) "A distribui ção de calcärio não ē homogênea na sequéncia vertical. Notam-se porém algumas tendēncias relevantes - o teor médio de calcārio é maior nos poços, que representam as partes superiores da colu na".

Um sērio problema na interpretação dos resultados da queles autores está implīcito na anālise dos teores totais de $\mathrm{CaCO}_{3}$, não diferenciando cimento e nödulo carbonätico.

Segundo MEZZALIRA (1974), "tanto nos afloramentos como nos testemunhos de sondagens, as zonas de cimento calcārio in terpõem-se a värias alturas às zonas não calcīferas, fato aliās bem observado por FREITAS (1955, p. 31) quando afirmou, "baseado em testemunhos de sondagem, que o arenito calcário ocorre em qualquer posição altimétrica dos perfis".

SETZER (1948), ALMEIDA \& BARBOSA (1953) e FREITAS (1955) utilizaram o critērio de cimentação para a subdivisão da Forma ção Bauru no Estado de São Paulo.

Achamos que não è vālido o uso da cimentação como um critērio estratigräfico pelos seguintes motivos:

- Tanto nos poços por nós estudados, como nos poços de São José do Rio Preto estudados por PIERUCETI \& BRANDT NETO (1974), as variações dos teores de carbonato de cālcio não se guem qualquer padrão.

- O estägio atual de cimentação pode ser atribuído a uma dissolução e reprecipitação epigenética,principalmente nas zonas superficiais (HASUI, 1969). 
- O carbonato de cālcio é em parte autígeno, provenien te de alterações intra-estratais de augitas.

Por outro lado, as observações de campo e de laborató rio deste trabalho, levam a concluir que, a maior ou menor ocor rēncia de nōdulos carbonāticos è importante critério estratigrā fico da Formação Bauru.

3.3 - ORIGEM DO CARBONATO DE CÂLCIO

o cimento calcifero (segundo MEZZALIRA) ocorrente nos diversos termos litológicos da Formação Bauru, tem sido objeto de especulação por parte de diversos autores que o estudaram,fal tando contudo dados elucidativos sobre sua possivel origem.

o cimento carbonātico estaria segundo FREITAS

ligado à precipitação quīmica mas, as observações deste trabalho sugerem que pelo menos parte do carbonato é proveniente de alte rações intra-estratais de augitas (autigeno).

Para primeiro caso, FREITAS aponta como fonte de $\mathrm{CaCO}_{3}$ a alteração e lixiviação de feldspatos e minerais ferromagnesia nos de basaltos.

Acredita-se que por processos diagenéticos de percola ção e lixiviação, o carbonato de cālcio,originalmente como cimen to, migrou e reprecipitou-se formando nódulos carbonāticos. 
CAPITULO 4

MINERAIS PESADOS

4.1 - METODOLOGIA

Apōs a anālise granulométrica dos sedimentos foram se paradas as frações $0,250-0,125 \mathrm{~mm}$ (areia fina) e 0,125-0,062m (areia muito fina) para añ̄ise de minerais pesados.

As frações acima e abaixo destes limites foram rejeita dos pelo fato de apresentarem pesados em volume muito pequeno (frações grossas) ou de seu estudo ōptico ficar dificultado (fra ções finas).

A separação das frações leve e pesada foi efetuada em funis apropriados por meio de bromoförmio de $D=2,89$.

Para aumentar a concentração de minerais pesados trans parentes, os opacos magnēticos (magnetita e ilmenita) foram par cialmente eliminados com imã manual.

os grãos na maioria dos casos se apresentaram cober tos por uma pelicula limonitica que dificultava as identifica ções. Fez-se então, a lavagem do material com ácido clorídrico $(30 \%)$ em um vibrador ultrasonico para eliminação desta pelîcula. Em algumas amostras analisou-se o material não atacado para ob servação de certas estruturas carbonäticas (augitas com bordas calcitizadas).

A seguir foram montadas lāminas com as frações pesadas daquelas duas granulações em associação total microquarteada. 0 meio de montagem foi o Bālsamo do Canadá $(n=1,56)$ : Para algu mas amostras em que apareceram dūvidas na identificação dos mine rais, em beneficio da exatidão de determinação ōptica, foram usa das tambēm montagens não permanentes com lïquido viscoso Aroclor $(n=1,64)$. 
As montagens com Aroclor apresentaram a vantagem de permitir a rotação de grãos para posições favorāveis à observa ção de figuras de interferência. Os minerais como apatita e sil limanita em montagem com Aroclor perdem quase totalmente o rele vo e diferenciam-se mais nitidamente de outros minerais incolo res de häbitos parecidos (COUTINHO \& COIMBRA, 1974).

Alguns minerais de identificação öptica duvidosa foram confirmados roentgonograficamente.

A frequencia relativa de cada mineral foi obtida apōs contagem de 100 grãos de minerais pesados transparentes e não micāceos por fração granulométrica analisada.

Apōs a contagem foi realizada uma varredura completa na lâmina, e os minerais com frequencias menores que $1 \%$ foram mar cados como TR (traços).

Os resultados estão apresentados sob a forma de tabe las (Tabelas VII e VIII). Nas tabelas, alēm das frequências ré lativas dos minerais estão computados os tipos de granadas e pi roxēnios presentes.

4.2 - FEIÇÕES PRINCIPAIS DOS MINERAIS PESADOS TRANSPARENTES NÃO MICĀCEOS DA FORMAÇÃO BAURU

Aqui serão discutidas as feições principais dos mine rais pesados transparentes não micáceos ordenados por frequéncia de ocorrēncia decrescente.

TURMALINA -

Predominam as formas equidimensionais ("esféri cas") bem arredondadas; as formas prismáticas de bordos arredondados (Estampa 1 - Fotomicrografia E) aparecem secundariamente, e as prismā ticas com terminações euhedrais pouco arredonda das são mais raras (Estampal - Fotomicrografia F). 
São frequentes os grãos de coloração castanha de turmalinas ferromagnesianas, e mais raras as variedades verdes (shorlitas), amarelas (magne sianas), azuis (indicolitas) e as incolores.

são frequentes, principalmente para as indicolj tas, grãos provenientes da fragmentação trans versal dos prismas, os quais são equidimensió nais ("esfēricos") bem arredondados (Estampa 1 - Fotomicrografia D), pouco pleocróicos dando boas figuras de interferencias (figuras de eixo ōptico).

ZIRCAO -

GRANADA -
Apresentam-se incolores e raramente coloridos (róseos e amarelo-esverdeados). Localmente, os róseos podem ser abundantes (ärea de Franca). São mais frequentes as formas equidimensionais ("esfēricas") bem arredondadas (Estampa 2 - Fo tomicrografia A), aparecendo secundariamente, as formas prismáticas de bordos arredondados (Es tampa 2 - Fotomicrografia C) e prismāticas bip $\bar{j}$ ramidais (Estampa 2 - Fotomicrografia $B$ ). Este mineral é facilmente confundido com xeno tima e é possivel mesmo, que uma pequena parcé la dos zircões, seja na realidade, constituida de xenotima.

São frequlentes os zircões com inclusões, e com zoneamento fraturado.

São mais comuns as granadas de coloração rōsea a incolor, sendo ma is raras as andraditas de co loração amarela, amarelo-esverdeadas e vermelho-amareladas, aparecendo ainda raramente grana das de coloração castanha, variedades mais tita nifferas de andraditas, denominadas schorlomitas. Predominam as formas equidimensionais ("esféri cas") bem arredondadas (Estampa 1 - Fotomicrogra fia A). 
São frequentes alterações superficiais (picotea mento), formando padrões superficiais retangula res ou losangulares (Estampa 1 - Fotomicrografias $B$ e C).

Apresentam, às vêzes, estruturas sageniticas (in clusões de agulhas de rutilo).

\section{PIROXENIO - Augita:}

Apresentam-se alongadas e arredondadas (Estampa 4 - Fotomicrografia A) comumente com alterações formando denteamentos (serrilhamentos) parale los ao eixo c (Estampa 4 - Fotomicrografia B). São mais frequentes as de coloração esverdeadas, sendo raras as de coloraçōes amarelo-esverdeadas e castanho esverdeadas.

São comuns, nas amostras não atacadas por ācido, augitas com bordas substituidas por carbonatos (Estampa 4 - Fotomicrografias C e D).

Algumas augitas apresentam partição caracterís tica de dialágios.

Egirina:

Tem o mesmo comportamento da augita, diferindo apenas por sua coloração verde esmeralda, extin ção reta e elongamento (Estampa 4 - Fotomicro grafia E).

Como a augita e egirina formam uma série isomor fa, torna-se muito difícil a distinção de termos intermediārios. Foram todos os grãos contados como augitas, anotando-se a presença de egiri nas, quando necessārio.

Titano-augita:

Aparece com o mesmo comportamento da augita di ferindo apenas por apresentar cor castanha. Por ser difícil tambēm a separação com a augita, fo ram todos os grãos computados em augita, anotan do-se a presença de titano-augita, quando reque rido. 

relos e vermelho amarelados, raramente com cor rōsea.

Exibem comumente um serrilhado nas bordas, para lelo ao eixo c. São comuns também evidéncias de dissolução, conferindo à superfície do mineral um padrão reticulado, sugerindo escamas (Estam pa 3 - Fotomicrografias A, B e C).

EPIDOTO -

São mais frequentes os de coloração esverdeada, verde limão (pistachitas), parecendo ainda os de coloração verde claro a incolores (zoisita e clinozoisita).

0correm com formas alongadas (Estampa 5 - Foto micrografias $A$ e C) e equidimensionais (Estampa 5 - Fotomicrografia B) arredondadas ou sub-arre dondadas.

Raramente aparecem com alterações superficiais formando um escamamento como da estaurolita.

RUTILO -

Apresenta coloração avermelhada, amarelada e vermelho amarelada. Alguns são castanhos, qua se opacos, sendo identificados apenas com a in serção de lente convergente.

São equidimensionais sub-arredondados e prismä ticos sugerindo terminações piramidais (Estampa 2 - Fotomicrografias $D$ e E).

Exibem por vezes geminações em joelho (Estampa 2 - Fotomicrografia G), em coração ou cotovelo (Estampa 2 - Fotomicrografia H), e com estrias longitudinais e obliqquas (geminação polissintētica - Estampa 2 - Fotomicrografia F). 
Incolores, com formas alongadas sub-arredondadas (Estampa 4 - Fotomicrografia F), raramente exibindo formas alongadas ou equidimensionais bem arredondadas.

SILLIMANITA -

Incolores, com formas alongadas sub-arredonda das. Raramente aparecem com formas alongadas ou equidimensionais bem arredondadas.

Raros são os grãos de sillimanita fibrosa brolita).

ANATASIO -

TITANITA -

Predominam os grãos de coloração amarela, sendo raros os incolores e os de tonalidades levemen te azuladas.

Comumente aparecem com contorno quadrado e bise lado por pirâmides (Estampa 4 - Fotomicrografia H), dando figura de eixo optico centrado e iso tropia.

Sua forma euhedral sugere tratar-se de um mine ral autígeno na Formação Bauru.

São incolores ou de coloração amarela clara.Apa recem com formas equidimensionais ("esféricas") ou ovöides bem arredondadas (Estampa 4 - Fotomi crografia $G$ ), ou equidimensionais sub-arredonda das.

Apresenta-se comumente com incrustações e inclu sões.

Apresentam coloração castanho avermelhada escu ro. São características as formas cūbicas, al guns grãos com arestas vivas demonstram peque no transporte (Estampa 5 - Fotomicrografias $D$, $E$ e F). Normalmente tem comportamento anisötro po e geminações tipo polissintética.

Comumente os grãos têm o mesmo tamanho, em tor no de 100 microns e podem por vēzes exibir leú 


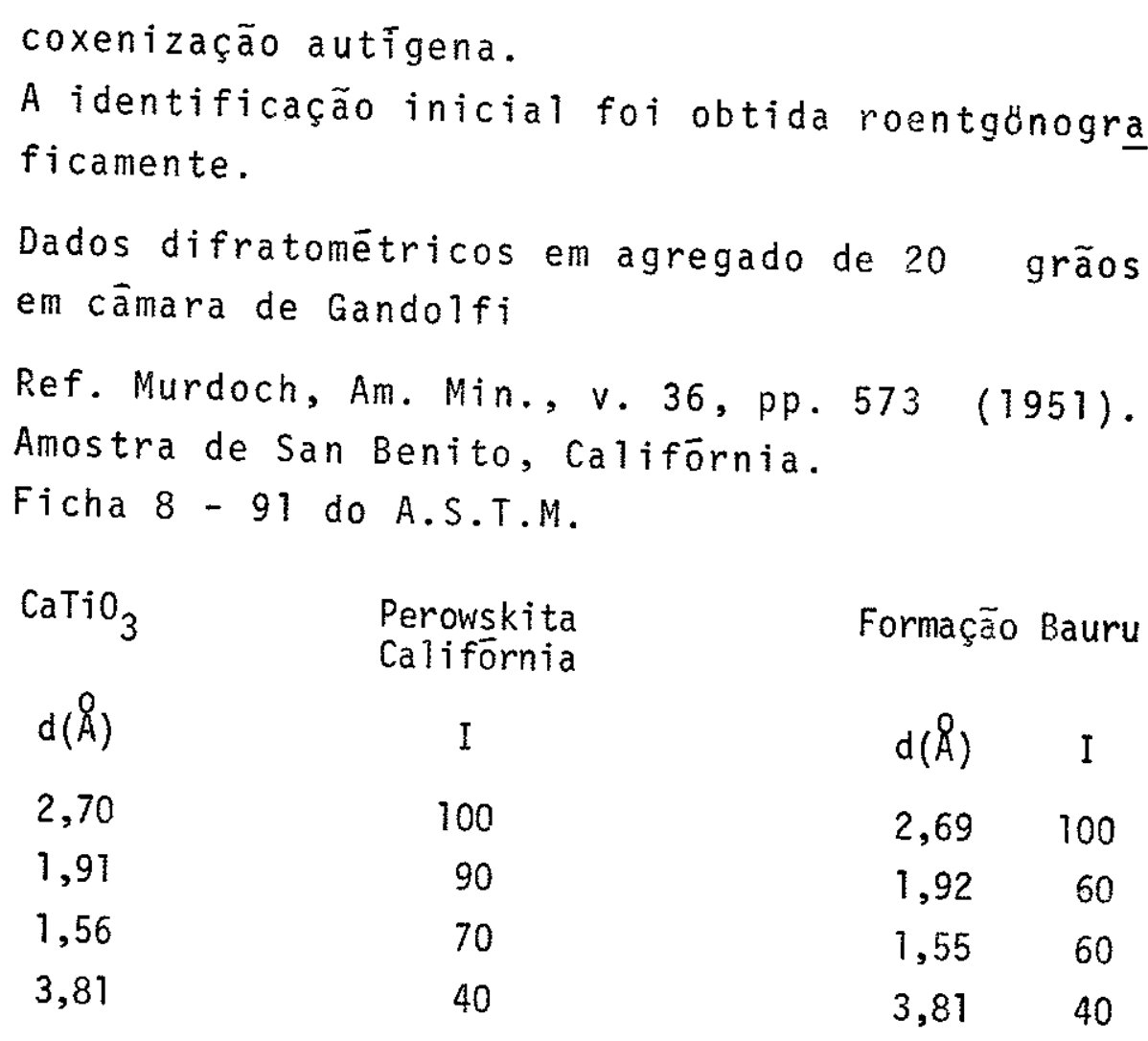

As intensidades menores tambëm coincidem, mos trando com isto que o material analisado é rea mente perowskita.

APATITA -

Incolores, com formas ovöides (Estampa 3 - Foto micrografia D) e alongadas bem arredondadas (Estampa 3 - Fotomicrografia E).

Apresentam-se em geral com inclusões, frequente mente dispostas paralelas ao elongamento do grão.

MONAZITA - Incolores, ou com coloração amarela clara. Apa recem com formas ovóides e equidimensionais("és féricas") bem arredondadas.

DUMORTIERITA - Mineral extremamente raro, ocorrendo apenas um grão na amostra PB - 28 (fração 0,250-0,125 mm) e um grão na amostra $P B-62$ (fração 0,125 $0,062 \mathrm{~mm})$. 


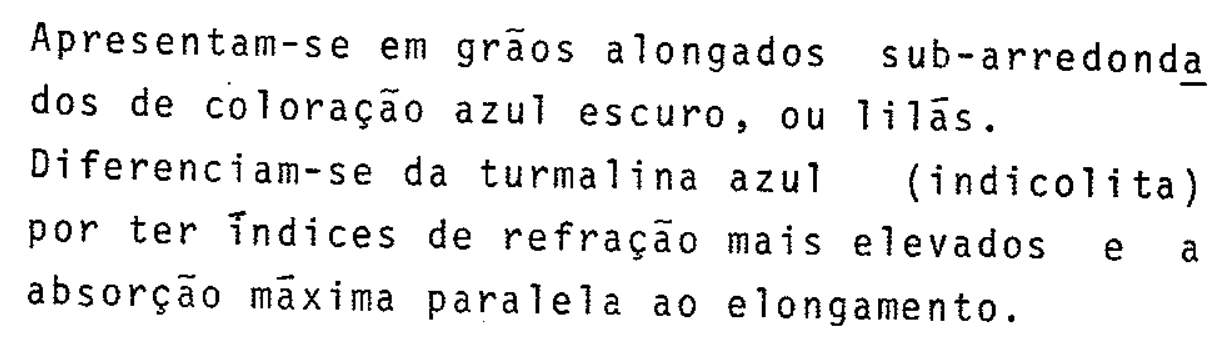

ESPINELIO - Mineral extremamente raro, ocorrendo apenas um grão na amostra $P B-37$ (fração $0,250-0,125 \mathrm{~mm}$ )

4.3 - ANALLISE DE FREQUENCIAS DOS MINERAIS PESADOS TRANSPARENTES NÃO MICĀCEOS

As Tabelas IX e $X$ mostram frequencias dos minerais nas duas frações granulomëtricas analisadas.

4.3.1 - Frequência média

E a média aritmética das frequéncias do mineral em to das as amostras analisadas.

Verificou-se que, na: 
Fração 0,250 - 0,125 mm: apenas nove minerais (zircão, turmalina, granada, augita, estaurolita, epidoto, rutilo, ciani ta e perowskita) perfazem uma somatōria de frequéncias igual a $97,10 \%$ do material analisado.

Fração 0,125 - 0,062 mm: apenas dez minerais (zircão, turmalina, granada, augita, estaurolita, epidoto, rutilo, ciani ta, perowskita e hornblenda) perfazem uma somatöria de frequên cias igual a $97,27 \%$ do material analisado.

Comparando as frequencias dos minerais nas duas fra ções granulomētricas, verificamos que alguns minerais como zị cão, rutilo, anatāsio, perowskita e apatita são mais frequentes na fração $0,125-0,062 \mathrm{~mm}$, enquanto turmalina, granada, augita, estaurolita e cianita são mais frequentes na fração $0,250-0,125 \mathrm{~mm}$.

E necessārio esclarecer que as frequēncias obtidas são relativas. A baixa frequencia relativa de um mineral numa fra ção não significa que este mineral apresenta baixa frequencia ab soluta, pois pode acontecer que a alta frequencia relativa de um mineral mascare as frequencias relativas dos demais.

outros fatores influem para que o mineral se concentre em determinada fração granulomëtrica:

Rutilo, zircão e perowskita se encontram preferencial mente na fração $0,125-0,062 \mathrm{~mm}$ devido aos seus altos pesos es pecificos (superiores a 3,8 ); enquanto turmalina, augita, cian ta e estaurolita se concentram na fração $0,250-0,125 \mathrm{~mm}$ devido aos seus pesos especificos inferiores a 3,8 . Tais concentrações diferenciais por densidade são correlacionadas aos tamanhos hi drāulicos de cada mineral pesado (HUBERT, 1971), não determina dos no presente trabalho na ausência de dados em frações inferio res a $0,062 \mathrm{~mm}$.

Outras propriedades como dureza, clivagem, fratura, for ma, tamanho original dos minerais na rocha matriz, condicionam tambēm a concentração dos minerais numa fração granulométrica. São estes certamente os fatores que mais influem, por exemplo, na presença de granada, de elevado peso específico, limitada em grande parte, às frações grossas. 


\section{3 .2 - Frequência de ocorrência}

Esta frequencia porcentual è obtida dividindo o nümero de amostras nas quais o mineral estā presente pelo núméro total de amostras.

Verificamos que:

Fração $0,250-0,125 \mathrm{~mm}$ : apenas nove minerais (zircão, turmalina, granada, augita, estaurolita, epidoto, rutilo, horn blenda e cianita) aparecem em mais de $25 \%$ das amostras analisa
das.

Fração 0,125 - 0,062 mm: apenas onze minerais (zircão, turmalina, granada, augita, estaurolita, epidoto, rutilo, horn blenda, cianita, titanita e perowskita) aparecem em mais de $25 \%$ das amostras analisadas.

\subsection{3 - Frequência de classes}

A partir das amostras nas quais o mineral estā presen te $\bar{e}$ apresentada uma classificação segundo a sua abundāncia.

Foi considerado super-abundante o mineral com frequên cia superior a $50 \%$, abundante entre 10 a $50 \%$, comum entre 2 a $10 \%$ e raro entre 0 a $2 \%$, conforme classificação proposta por COUTINHO \& COIMBRA (1974).

4.4 - INDICES DE MATURIDADE MINERALÖGICA

\subsection{1 - Metodologia}

Os indices,por serem multivariantes, apresentam Ihores resultados na interpretação de āreas-fonte.

0 indice $I_{1}(Z T R=$ zircão + turmalina + rutilo) tem sido normalmente usado como indice de maturidade mineralógica 
(HUBERT, 1962). Foi calculado a partir da soma das frequéncias porcentuais.

os indices $\mathrm{I}_{2}, \mathrm{I}_{3}$ e $\mathrm{I}_{4}$, propostos neste trabalho, rela cionam minerais instāveis com minerais estāveis.

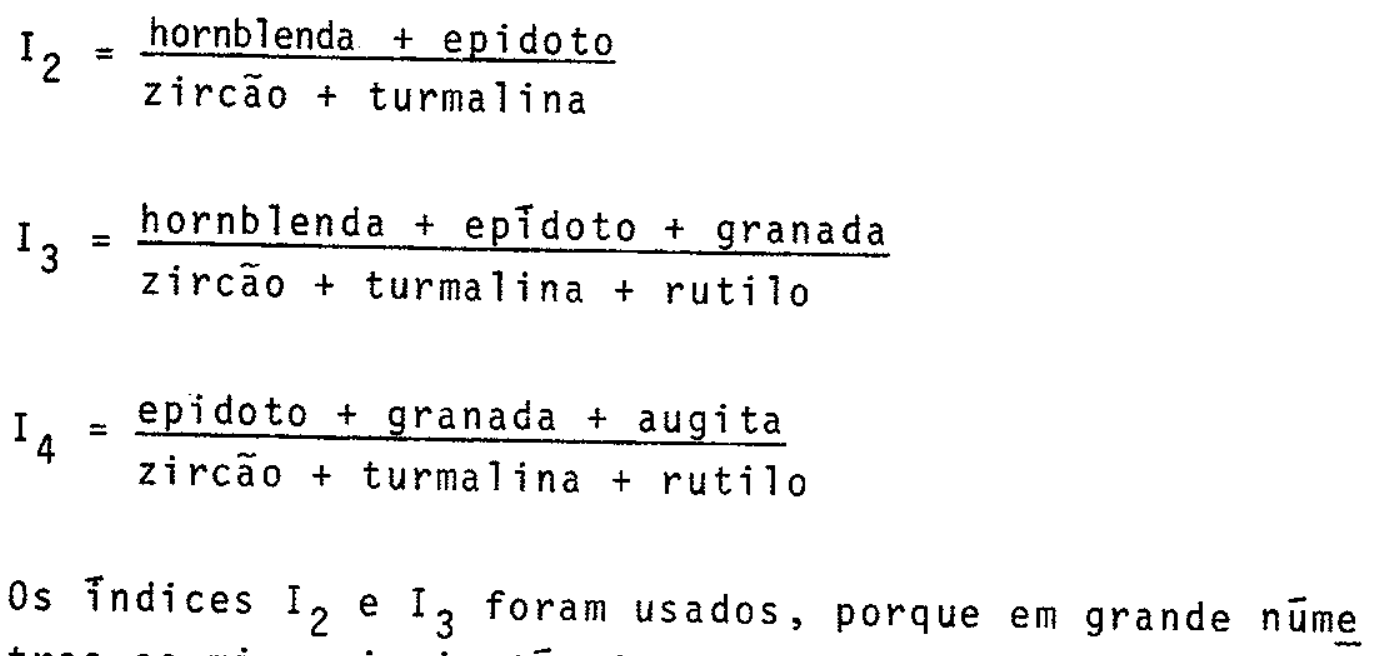
ro de amostras os minerais instäveis mais frequentes são epidoto, granada e hornblenda, que indicam uma maior ou menor proveniencia de rochas metamörficas (gnaisses e xistos).

0 indice $I_{4}$ foi usado, porque em grande nümero de amos tras o mineral instāvel mais frequente é a augita, que evidencia contribuição de rochas bāsicas.

os indices $\mathrm{I}_{2}, \mathrm{I}_{3}$ e $\mathrm{I}_{4}$ como razões entre minerais não puderam ser calculados a partir das frequencias porcentuais. As frequencias porcentuais dos minerais foram inicialmente classifi cadas por postos:

Frequencias porcentuais

Pos to

$\begin{array}{rrrr}0 & \text { a } & 9 \% & 1 \\ 10 & \text { a } & 19 \% & 2 \\ 20 & \text { a } & 29 \% & 3 \\ 30 & \text { a } & 39 \% & 4 \\ 40 & \text { a } & 49 \% & 5 \\ 50 & \text { a } & 59 \% & 6 \\ 60 & \text { a } & 69 \% & 7 \\ 70 & \text { a } & 79 \% & 8 \\ 80 & \text { a } & 89 \% & 9 \\ 90 & \text { a } & 100 \% & 10\end{array}$


Os cālculos dos indices foram feitos então a partir das relações entre os postos de frequência.

\subsection{2 - Apresentação dos resultados}

As Tabelas XI e XII mostram os indices de maturidade mineralōgica ( $\mathrm{I}_{1}, \mathrm{I}_{2}, \mathrm{I}_{3}$ e $\mathrm{I}_{4}$ ) nas duas frações granulométricas das amostras estudadas.

os indices $\mathrm{I}_{2}, \mathrm{I}_{3}$ e $\mathrm{I}_{4}$ são geralmente mais altos na fração $0,250-0,125 \mathrm{~mm}$, devido ao fato dos minerais como grana da e augita se concentrarem entre 0,250 - 0,125 mm e zircão e rú tilo na fração $0,125-0,062 \mathrm{~mm}$.

\subsection{3 - Anālise de frequtência do indice ZTR}

Os valores de ZTR foram classificados para facilitar a anālise de variações de frequência. As Tabelas XIII e XIV mos tram suas variações em amostras de superficie. Nas Tabelas XV e XVI as variações se referem às amostras de sondagem.

Comparando as Tabelas XIII e XIV com as Tabelas XV e $X V I$, verifica-se que tanto na fração 0,125 - 0,062 mm como na fração $0,250-0,125 \mathrm{~mm}$, os valores de ZTR para amostras de son dagem são menores que os de amostras de superficie. Isto pode estar ligado ao fato das amostras de superficie provirem prefe rencialmente de niveis estratigráficos superiores, os quais por sua vez apresentaram maiores valores de ZTR, cono pode ser obser vado nos perfis de sondagem; e secundariamente pode estar iigado ao fato das amostras de superficie estarem parcialmente altera das causando com isso uma eliminação dos minerais mais instāeis e consequlentemente um enriquecimento de minerais ultra-estáveis (ZTR). 
Foram encontrados alguns minerais pesados diagnōsti cos para äreas-fonte especificas, enquanto outros proviriam de fontes diversificadas.

Minerais como zircão, turmalina e rutilo primariamen te extraĩdos de rochas igneas e metamōrficas, aparecem na Forma ção Bauru com formas equidimensionais muito bem arredondadas, sú gerindo como fonte sedimentos preexistentes: Formação Furnas, Grupo Tubarão e Formação Botucatu, todas extremamente ricas nes tes minerais (SUGUIO et al., 1974).

Em algumas ocorrências localizadas (ärea de Franca), 0 zircão redondo róseo pode comparecer abundantemente. Sua fonte, em tais casos, poderia ser traçada diretamente nos quartzitos vizinhos do Grupo Canastra.

Considera-se uma contribuição positiva do presente tra balho, a descoberta de perowskita em relativa abundancia por toda a ārea da Formação Bauru circunscrita ao norte do Rio Tietê. Este mineral forma-se primariamente em rochas alcalinas insatu radas, especialmente as bāsicas, ultrabāsicas e seus tufos, mui to concentrados no Triāngulo Mineiro.

HUSSAK (1906 in BARBOSA et al., 1970), deu conhecimen to da existência de tufos alcalinos ricos em perowskita, em ube raba.

Segundo HASUI (1968) "Perowskitas comparecem na Forma ção Uberaba com grãos menores que $0,2 \mathrm{~mm}$, em quantidades apré ciāveis em alguns delgados estratos da metade inferior da se quência. A procedência da perowskita deve relacionar-se com rochas alcalinas".

As rochas do vulcanismo alcalino do Triângulo Mineiro contêm perowskita, e os resíduos pesados da fäcies uberaba são ricos em perowskita (BARBOSA et al., 1970).

Em algumas perowskitas de ocorrencia restrita, obser 
vou-se formas cübicas com arestas vivas, sugerindo pouco retraba Ihamento e fontes mais próximas, como na região de Jaboticabal, onde temos uma pequena ocorrēncia de rochas alcalinas. Esta al calina de Jaboticabal foi descrita e datada por MADUREIRA FILHO et al. (em preparação), que observaram perowskitas como acessō rio. Questiona-se a idade terciäria (54 m.a.) desta alcalina,ob tida por datação geocronolögica e acredita-se numa idade mais antiga (prē-Bauru).

A presença marcante de augitas e titano-augitas, prin cipalmente nas partes inferiores da Formação Bauru, evidenciam contribuição maciça de rochas bäsicas (basaltos e diabäsios) da Formação Serra Geral do Grupo São Bento no inīcio da sedimenta ção Bauru, diminuindo para o topo da unidade. Secundariamente, podem ser provenientes de rochas alcalinas bäsicas e ultrabási cas do Triângulo Mineiro.

A contribuição mais substancial dos basaltos na parte inferior da Formação Bauru, no Estado de São Paulo, havia sido notada por FREITAS (1955).

Anatäsios euhedrais evidenciam sua origem autigena. Al guns grãos arredondados se derivariam de sedimentos preexistentes.

A riqueza em granadas, principalmente na parte norte da Formação Bauru, está ligada provavelmente à contribuição de xistos granatīferos do Grupo Araxā (Prē-l).

Segundo BARBOSA et al. (1970) os xistos do Grupo Araxá, em geral apresentam como acessörios granada, que pode se cons tituir num mineral importante, rutilo, zircão, turmalina e estau rolita. Esta granáda é presumivelmente almandina, tipo tambēm dominante no Arenito Bauru. Variedades pardo escuro ou amare10 (schorlomita ou andradita) teriam fonte provāvel nas alcalinas do Triāngulo Mineiro.

Cianita: proveniente de rochas metamörficas (xistos) do Grupo Araxā (Pre- $-\ell)$, de xistos e quartzitos do Grupo Canastra $($ Prē-l), e em parte dos metassedimentos do Grupo Açungui (Pre- $-\ell$ ). Em todos estes grupos, obedecendo a progressão metamörfica do ti po Barroviano, a cianita forma zona obrigatōia. 
Estaurolita: da mesma forma que para cianita, e pelas mesmas razões, a fonte primäria de estaurolita deve ser baseada nos Grupos Araxā, Canastra e Açungui. Grãos mais arredondados devem provir de sedimentos preexistentes,por exemplo Botucatu (SUGUIO et al., 1974).

Epidoto: proveniente de rochas ígneas äcidas (grani tos) e metamorfitos dos Grupos Araxā, Canastra e Açungui.

Hornblenda: proveniente de rochas metamörficas dos Grupos Araxā, Canastra e Açungui,migmatitos especialmente e meta mörficas metabasiticas de baixo a alto grau.

Sillimanita: provenientes de rochas metamörficas de alto grau (gnaisses, migmatitos e granulitos) do embasamento cris talino (Prē-l indiviso) e de xistos do Grupo Araxă.

Titanita: proveniente de rochas igneas àcidas (grani tos) e gnaisses e migmatitos de composição granitica a granodio rítica do embasamento, onde é acessōrio comum. Talvez em parte de rochas alcalinas (sienitos).

Apatita: acessörio universal em rochas ígneas e meta mörficas. Sua presença deveria ser notada com muito mais fre quência, não fosse sua alta instabilidade em condições superfi ciais.

Monazita: proveniente de gnaisses e granulitos (rochas charnockiticas) do embasamento mais antigo, secundariamente de pegmatitos.

Barita: acredita-se que a barita ocorra localmente co mo cimento, associada ao cimento carbonático, podendo aparecer sob a forma de grãos clásticos em conglomerados e arenitos con glomerāticos intraformacionais. A barita, originalmente de c $\bar{i}$ mento, teria sofrido então um pequeno transporte concentrando-se em conglomerados e arenitos conglomeráticos superiores.

Interessante assinalar tambëm a ausência de certos mi nerais razoavelmente abundantes em sedimentos pós-cretäceos de outras āreas brasileiras. Um deles,por exemplo, $\vec{e}$ andaluzita, muito comum no Grupo Barreiras da costa Oriental (COUTINHO \& 
COIMBRA, 1974) e absolutamente ausente no Bauru. Aparentemente a ārea fonte metamōrfica (compreendendo especialmente os Grupos Açungui, Araxä e Canastra) se submeteu a esquema de metamorfis mo Barroviano, cujas assembléias prescindem da andaluzita.

\section{6 - MATURIDADE MINERALÓGICA}

Usando a escala de maturidade mineralógica de SINDOWSKY (in PETTIJOHN, 1957) descrita abaixo, verificamos que a Formação Bauru apresenta:

Fração 0,250 - 0,125 mm (Tabela VII)

- iguais proporções de minerais de alta estabilidade (turmalina) e meta-estāveis (granada);

- iguais proporções de minerais de alta estabilidade (zircão) e minerais meta-estäveis (augita);

Fração $0,125-0,062 \mathrm{~mm}$ (Tabela VIII)

- iguais proporções de minerais de alta estabilidade (zircão e turmalina) e minerais meta-estáveis (grana da);

- iguais proporções de minerais de alta estabilidade (rutilo) e minerais meta-estāveis (augita).

ESCALA DE ESTABILIDADE QUIMICA DE SINDOWSKY

( in PETTIJOHN, 1957)

$$
\begin{aligned}
& 1 \text { - Zircão } \\
& 2 \text { - Rutilo } \\
& 3 \text { - Turmalina } \\
& 4 \text { - Estaurolita } \\
& 5 \text { - Cianita } \\
& 6 \text { - Hornblenda } \\
& 7 \text { - Granada }
\end{aligned}
$$




$$
\begin{array}{r}
8 \text { - Augita } \\
9 \text { - Apatita } \\
10 \text { - Olivina }
\end{array}
$$

A mistura de minerais instäveis com minerais estāveis classifica o sedimento como mineralogicamente imaturo.

A imaturidade mineralógica de um sedimento pode ser explicada:

velocidade de erosão maior do que de decomposição na ārea-fonte (intemperismo), levando a condições de räpi da sedimentação.

Condições de clima na ārea fonte com tendēncias a semi-ārido (pouco intemperismo quîmico) durante a sedimenta ção.

A primeira hipótese esbarra no problema de não serem encontradas evidēncias de rāpida sedimentação para a Formação Bau ru, muito pelo contrārio, a Formação Bauru parece ter se deposi tado sob condições calmas de sedimentação, como parece demons trar.

A segunda hipótese encontra apoio na existência de de pósitos de calcārios na Formação Bauru considerados por SUGuIo et al. (1975) como depósitos similares a caliches (depōsitos de clima semi-ārido). A constituição em isōtopos estāveis de carbo no e oxigentio quando confrontada com a de amostras de caliche da Africa confirmou a idēia de deposição desses sedimentos em àgua doce, talvez sob condições de clima seco. Esta hipōtese por ou tro lado é contraditada pela existência de fösseis de rēpteis que deveriam ter vivido sob condições climäticas mais amenas do que as semi-āridas.

Segundo SUGUIO et al. (1975) - "Podem ser consideradas evidências de clima ümido os seguintes fatos: presença de fós seis, mormente de vertebrados de grande porte (rēpteis e quelö nios), valores relativamente baixos de isōtopos de oxigēnio e valores muito baixos da relação $\mathrm{TiO}_{2} / \mathrm{Al}_{2} \mathrm{O}_{3}$ e principalmente a presença generalizada de minerais de argila do grupo da atapulgi 
ta, tanto nos sedimentos calcārios como nos sedimentos detriti cos associados".

Acredita-se que o clima da Formação Bauru foi ümido al ternado com fases secas (ARID, 1973), no inîcio da sedimentação e para o topo as fases secas se tornaram mais frequentes e mais rigorosas. Isto é justificado pelo fato dos nödulos carbonäti cos serem maiores e mais frequentes para o topo, e pela presença de conglomerados de pelotas de argila no topo da Formação Bauru.

Os conglomerados de pelotas de argila foram descritos anteriormente por ARID (1973), que assim se manifestou sobre a sua origem: "Os leitos de argila, depositados durante a inunda ção da planīcie, nos períodos de chuvas, com a chegada da esta ção seca e a consequente retirada das äguas, aqueles depósitos ficaram expostos à evaporação, endureceram-se e litificaram-se. $\mathrm{Na}$ pröxima inundação, as correntes de enchente ou os novos cur sos foram capazes de erodir esses leitos e transportar os frag mentos a maior ou menor distāncia, depositando-os em associação lateral com outras camadas".

Acredita-se que estes conglomerados de pelotas de argi la representem fases torrenciais dentro de um intervalo semi-ärí do, onde as pelotas de argila formadas por ressecamento são car readas formando os niveis conglomeräticos.

4.7 - DISSOLUÇÃO INTRA-ESTRATAL

Alguns minerais instāveis da Formação Bauru, como au gita, titano-augita, hornblenda, estaurolita, granada e epidoto, apresentam evidências de ação incipiente de soluções intra-estra tais, expressas por corrosão, picoteamento e dissolução ao longo do eixo cristalogräfico principal (Estampas 1, 3 e 4 ).

A raridade e mesmo ausēncia de minerais mais instāveis no Grupo Barreiras (Terciärio), como hornblenda, granada, diops $\vec{I}$ dio, epidoto, hiperstênio e titanita, segundo COUTINHO \& COIMBRA (1974) se deve a pouca estabilidade quỉmica destes minerais, ten 
do eles se destruído, ou na ārea fonte (intemperismo), ou nos sedi mentos jä depositados (soluções intra-estratais).

Para a Formação Bauru, acredita-se que o intemperismo na fonte $\bar{e}$ o fator que condicionou o aparecimento ou não de mine rais instāveis em sua assemblēia. A simples presença de mine rais instāveis, como augita, hornblenda, granada e epidoto mos tra que a dissolução intra-estratal não é tão importante. Se o processo da dissolução intra-estratal fosse realmente efetivo, a Formação Bauru (Cretāceo Superior) deveria ter menos minerais instāveis.

4.8 - NUMERO DE ESPECCIES MINERALÖGICAS

O nümero de espécies mineralōgicas no resíduo pesado de um sedimento estā ligado tanto à diversidade de āreas-fonte, como à ação de soluções intra-estratais, a ūltima das quais ten de a eliminar as espécies mais instáveis, causando diminuição no seu nümero.

Acredita-se que a diversidade de äreas-fonte $\bar{e}$ o fator condicionante do grande nümero de espēcies mineralōgicas na for mação Bauru. Como retroafirmado a dissolução intra-estratal, em bora existente, mostra efeitos incipientes, de vajor global redu zido.

Analisando os valores ao longo do perfil de sondagem de General Salgado (Figura 31) vemos que o nümero de espécies di minui para a base da Formação Bauru, o que à primeira vista pare ceria evidência da atuação de soluções intra-estratais, visto que os sedimentos da base, mais antigos apresentam maior grau de diagênese. Todavia, na base do poço observamos apenas minerais instāveis como augita e granada. Se se quisesse explicar o pe queno nümero de espēcies na base apelando para a ação de dissolu ção intra-estratal dever-se-ia procurar explicação ainda mais problemática para a presença abundante de mineral tão instävel como augita. A presença de pequeno nümero de espëcies na base 
da unidade, estā ligada a certa homogeneidade de contribuição de äreas-fonte. No caso de General Salgado presume-se que as āreas- fonte estariam representadas ao tempo da erosão e alimentação, principalmente por rochas basālticas da Formação Serra Geral e xistos do Grupo Araxā.

As Tabelas XVII e XVIII mostram os resultados de fre quência de nummero de espēcies do residuo pesado de todas as amos tras estudadas.

Podemos observar que tanto na fração 0,125 - 0,062 mm como na fração $0,250-0,125 \mathrm{~mm}$, são mais frequentes as amos tras que se apresentam com 5 a 8 espēcies mineralögicas.

Comparando a Tabela XVII com a Tabela XVIII, verifica - se que de uma maneira geral a fração 0,125 - 0,062 mm è mais diversificada que a fração $0,250-0,125 \mathrm{~mm}$. A fração 0,125 $-0,062 \mathrm{~mm}$ apresenta amostras com atē 12 espécies, enquanto que fração 0,250 - 0,125 mm, observa-se um. mäximo de 10 espécies. 
CAPITULO 5

ANÁLISE DE SUPERFICIE DE TENDENCIA

5.1 - INTRODUÇÃO

A tēcnica de "trend surface analysis" è descrita em KRUMBEIN \& SLOSS (1963), KRUMBEIN \& GRAYBILL (1965) e HARBAUGH \& MERRIAN (1968). Foi primeiramente aplicada no Brasil por FUL FARO \& AMARAL (1970) em distribuição granulométrica de areias da praia do Tenörio (Litoral Paulista), e posteriormente aplicada por FOLFARO (1971) no estudo da evolução tectônica e paleogeográ fica da Bacia do Paranā. Atualmente esta tēcnica tem sido muito aplicada em diversos campos da Geologia, como Petrologia, Estra tigrafia, Tectónica, Geofisica, Hidrogeologia, etc...

os cālculos para o presente estudo foram realizados em computador a partir de um programa denominado DTREND, modif $\underline{j}$ cado do programa original produzido no Departamento de Ciēncias Geolōgicas da Northwestern University, E.U.A. O programa DTREND foi adaptado e modificado pelo Professor Doutor Gilberto Amaral, do Instituto de Geociēncias da U.S.P. Ele é escrito em lingua gem Fortran IV para o computador Burroughs B6600/B7700 do Centro de Computação Eletrōnica da U.S.P. Este programa fornece matri zes atē 60 grau e vārios testes destinados a avaliar a "força" ou grau de ajuste das vārias superfícies obtidas, na forma pro posta por ALLEN \& KRUMBEIN (1962) e KRUMBEIN \& GRAYBILL (1965) ou seja, a soma dos residuos ao quadrado, a porcentagem da soma to tal dos quadrados, o coeficiente de determinação e o coeficiente de correlação.

Durante o processamento foram usadas superfícies de até 60 grau. Mas como a aplicação da tēcnica para dados sedimen tolögicos enfrenta vārios problemas, como estão explicados aba so, optou-se pelo uso de superficie de 30 grau. 
Restringiu-se ainda a interpretação para mapas de ten dēncia que apresentaram coeficientes de correlação acima de $70 \%$ em superficies de 39 grau e com o porcento da soma total dos quadrados superior a $18 \%$.

A escolha destes limites quanto ao grau da superficie e o seu coeficiente de correlação, estā baseada na densidade de amostragem e no trabalho de HOWARTH (1967).

Muitos mapas de tendéncia foram eliminados,pois se con siderou apenas os mapas de tendēncia onde o nümero de amostras $\bar{e}$ três vezes superior ao nümero de coeficientes da superficie.

Usaram-se como limite, os valores obtidos por HOWARTH (1967), que aplicou "trend surface analysis" para vārias distrí buições de nümeros gerados ao acaso, aconselhando o uso de super fícies de 30 grau com o porcento da soma total dos quadrados ac $\bar{j}$ ma de $16,2 \%$, pois valores mais baixos podem estar ligados a dis tribuições ao acaso.

\subsection{1 - Parâmetros granulomētricos}

Sendo todas as amostras de superficie, devem elas se situar em diferentes niveis estratigräficos. A aplicação da têc nica de "trend surface analysis" com o objetivo de estabelecer a paleogeografia e as fontes dos sedimentos, estā sujeita a uma combinação de variāveis, que são a maior ou menor proximidade da fonte e estāgios mais ou menos energēticos durante a sedimentação.

os parāmetros granulométricos,por outro lado, apresen tam a vantagem de fornecer dados absolutos, enquanto os minerais pesados fornecem dados relativos de frequéncia. 


\section{1 .2 - Minerais pesados}

\subsubsection{1 - Frequência relativa dos minerais}

$\mathrm{Na}$ determinação de frequência de minerais pesados os dados obtidos expressam apenas frequencias relativas. No uso de mapas de tendéncia para anālise de äreas-fonte deve-se levar em conta que baixa frequencia de determinado mineral em uma amostra, relativamente a outros minerais, não significa baixa frequencia absoluta, pois pode acontecer que a alta frequencia relativa de um mineral mascare as frequéncias relativas dos demais.

0 uso de frequencias relativas de minerais nos sedimen tos é importante na interpretação de āreas-fonte, pois evidencia - quanto determinada fonte contribuiu para formação do sedimento. A frequencia absoluta de minerais pesadospode estar ligada tanto à contribuição de uma fonte como à ocorrência de horizontes de granulação maior onde se concentram hidraulicamente os minerais de densidade mais alta.

Se não houver variação considerāvel na paleogeografia e äreas-fonte durante o tempo de formação do registro sedimentar, as variações de ordem estratigräfica não serão significativas.

5.1 .2 .2 - Indices de maturidade mineralögica

Apesar de enfrentarem os problemas anteriormente des critos, os indices de maturidade mineralógica, por serem multi variantes, apresentam melhores resultados.

São usados värios indices $\mathrm{I}_{1}, \mathrm{I}_{3}$ e $\mathrm{I}_{4}$ e a comparação dos mapas de tendência dă uma boa idéia sobre a paleogeografia, mostrando a paleodrenagem e as āreas-fonte. 
5.2 - SUPERFICIES DE TENDENCIA DAS FREQUENCIAS DE MINERAIS PESA DOS

A partir dos mapas de tendēncia das frequéncias dos minerais pesados, caracterizou-se as suas possiveis āreas-fonte.

$$
\text { 5.2.1 - Cianita (Figuras } 1 \text { e 2) }
$$

De uma maneira geral a Formação Bauru apresenta uma superficie extremamente homogēnea quanto ao conteūdo de cianita, mostrando valores anómalos ligados a uma maior proximidade da ārea-fonte.

Tanto na fração $0,250-0,125 \mathrm{~mm}$ como na fração 0,125 - 0,062 mm aparecem altos valores a E-NE do mapa, demonstrando uma contribuição principalmente de rochas metamörficas do Grupo Canastra. Apresenta ainda valores anómalos a $S$ do mapa, eviden ciando uma provāvel fonte secundāria a partir de rochas metamōr ficas do Grupo Açungui afiorantes ao longo do Arco de Ponta Grós sa.

$$
5.2 .2 \text { - Turmalina (Figuras } 3 \text { e } 4 \text { ) }
$$

Apresenta superfícies de tendēncia tanto para a fra ção 0,250 - 0,125 mm como para a fração $0,125-0,062 \mathrm{~mm}$ com duas āreas distintas, separadas grosseiramente pelo Rio Tietē. A ärea Norte se caracteriza por baixas frequēncias e a ärea sul $\bar{e}$ extremamente rica em turmalinas.

Os mapas apresentam três possīveis äreas-fonte: NW, E-SE e W-SW, possiveis zonas de retrabalhamento de sedimentos paleo-mesozóicos da Bacia do Paranā. Corrobora esta idéia o fa to das turmalinas se apresentarem esféricas e betar arredondadas, 
evidenciando reciclagem.

\section{2 .3 - Granada (Figuras 5 e 6 )}

As superfícies de tendência das frequências de granada evidenciam na Formação Bauru duas äreas distintas: uma ao Norte e outra ao SUT, separadas grosseiramente pelo Rio Tieté.

Os mais altos valores de frequencia de granada estão situados principalmente a $\underline{N E}$ do mapa e estão ligados a uma maior proximidade da ärea-fonte, provavelmente representada pelos xistos granatíferos do Grupo Araxä.

Os mapas evidenciam ainda uma segunda ārea-fonte situa da a W-NW da ārea, ligada possivelmente a uma contribuição de gnaisses e migmatitos do Maciço Mediano Goiano.

\subsection{4 - Epidoto (Figura 7)}

A superficie de tendēncia de frequência de epidoto na fração $0,250-0,125 \mathrm{~mm}$ evidencia tambēm duas āreas distintas: uma ao Norte e outra ao Sul, separadas grosseiramente pelo Rio Tietê.

A ärea Norte ē pobre em epidoto, e os valores de frequência aumentam gradativamente para sul, demonstrando uma maior proximidade da ārea-fonte. Area-fonte constituida provavelmente de rochas metamörficas e granitos intrusivos do Grupo Açungui afloramentos ao longo do Arco de Ponta Grossa.

\subsection{5 - Estaurolita (Figura 8)}


mostrando um enriquecimento para $N W$ e $S E$, enriquecimento este 1 I gado a uma maior proximidade de āreas-fonte.

Como jā foi demonstrado nos mapas de tendência de turmalinas, as āreas-fonte a NW e SE se caracterizam por contribuição de sedimentos preexistentes. Isto leva a crer que a estaurolita esteja tambēm ligada ao mesmo retrabalhamento, pois segundo SUGUI0 et al. (1974) a Formação Botucatu ē rica em estaurolita, constituindo nestas condições, ärea fonte potencial para 0 mineral da Formação Bauru.

$$
5.2 .6 \text { - Rutilo (Figura 9) }
$$

A superficie de tendēncia de rutilo na fração 0,125. $0,062 \mathrm{~mm}$ sugere duas fontes: uma a $N$ W ligada ao retrabalhamento de sedimentos da Bacia do Paranā, a outra a E-NE parece estar 1 i gada em parte aos sedimentos da Bacia do Paraná e em parte aos quartzitos do Grupo Canastra.

5.3 - SUPERFICIES DE TENDÊNCIA DOS INDICES DE MATURIDADE MTNERALÓ GICA DA FORMAÇÃO BAURU

As superficies de tendēncia dos indices de maturidade mineralógica mostram duas äreas distintas; sul e norte, separadas entre si, grosseiramente pelo Rio Tietê.

o centro da ärea sul se caracteriza por uma assembiēia mineralógica constituída principalmente por minerais estāveis (zircão, turmalina e rutilo), apresentando com isso altos valores ZTR.

0 centro da ārea norte apresenta uma assemblēia minera lögica rica em minerais instāveis, apresentando com isso baixos valores ZTR.

Esta diferença estā ligada a proveniências dos sedimen 
tos a partir de fontes distintas.

Na anälise dos mapas de tendēncia do indice ZTR (Figuras 10 e 11), verificamos que os maiores valores, tanto para a fração 0,125 - 0,062 mm como para a fração $0,250-0,125 \mathrm{~mm}$, se encontram a SE e NW do mapa, āreas estas que tém como possiveis āreas-fonte, os sedimentos paleo-mesozöicos da Bacia do Parană. 0 fato dessas āreas apresentarem alto ZTR está ligado ao retraba Thamento daqueles sedimentos preexistentes, que por sua vez são extremamente ricos em minerais estäveis. Corroborando esta hipotese, os minerais estāveis (zircão, turmalina e rutilo) da Forma ção Bauru, se apresentam esfēricos e bem arredondados,evidencian do reciclagem.

Analisando as superficies de tendēncia do indice $I_{3}$, ve rifica-se a presença na fração $0,250-0,125 \mathrm{~mm}$ de três possîveis āreas-fonte (Figura 12): uma a $\underline{W}-\mathrm{NW}$, outra a $S$ e uma ültima a NE. Por outro lado, na fração $0,125-0,062 \mathrm{~mm}$ aparecem bem ca racterizadas duas fontes: uma a $\underline{N E}$ e outra a $\underline{S}$ (Figura 13). A fon te $N E$ que se acredita a principal, estä ligada à contribuição de granadas e epidotos das rochas metamörficas (xistos) do Grupo Arax $\bar{a}$.

A segunda fonte a sul estaria relacionada à contribuição de granadas e epidotos de rochas metamörficas aflorantes ao longo do Arco de Ponta Grossa.

A fonte $\underline{W-N W}$ parece tratar-se de uma contribuição secun dāria de rochas metamōrficas (gnaisses e migmatitos) do complexo Mediano Goiano.

Analisando $I_{4}$ (Figuras 14 e 15), verifica-se uma ünica fonte principal, ligada à contribuição de augitas a partir de ba saltos da Formação Serra Geral da região do Triângulo Mineiro.

As āreas da Formação Bauru que têm como possiveis fontes sedimentos preexistentes, aparecem com baixos valores nos ma pas de tendēncia $\mathrm{I}_{3}$ e $\mathrm{I}_{4}$. São äreas necessariamente deficientes em minerais instáveis (granada, epidoto, hornblenda e augita).

Em resumo, observa-se que as superficies de tendéncia dos indices evidenciam fontes diversificadas na contribuição dos 
sedimentos da Formação Bauru:

A NW e SE as contribuições seriam essencialmente de se dimentos preexistentes (sedimentos paleo-mesozóicos da Bacia do Paranà).

A fonte a NE se caracteriza por contribuição de rochas metamōrficas do Grupo Araxă e pelos basaltos da Formação Serra Geral.

A fonte a Sul é formada de rochas metamörficas afloran tes ao longo do Arco de Ponta Grossa.

5.4 - SUPERFICIE DE TENDENCIA DOS PARÂMETROS GRANULOMËTRICOS DA FORMAÇÃO BAURU

As superfícies de tendēncia dos parāmetros granulomētri $\cos$ da Formação Bauru, evidenciam uma bacia simples, onde supe $\underline{r}$ fícies de 30 grau apresentam coeficientes de correlação acima de $70 \%$.

A partir das superficies de tendência dos parāmetros granulométricos, verifica-se a existencia de trēs fontes princi pais de sedimentação da Formação Bauru.

5.4 .1 - Fonte a NW do mapa

Como já foi evidenciado nos mapas de tendência dos indi ces de maturidade mineralógica, trata-se de uma fonte formada por sedimentos preexistentes.

A Formação Bauru adjacente apresenta-se com clästicos mais grossos tanto em relação à distribuição total (Figura 16) como à distribuição areia (Figura 17). Apresenta ainda altos va lores na relação clästicos grossos/clästicos finos (Figura 18), evidenciando uma borda de bacia de sedimentação. 
Nesta região hā má seleção com altos valores de desvio padrão (Figuras 19 e 20), justificados pelo fato de tratar-se de borda de bacia.

Outra evidencia de borda de bacia são os altos valores da superficie de tendência do nümero de classes texturais (Figu ra 21).

\subsection{2 - Fonte a NE do mapa}

As regiões do Bauru, próximas a esta fonte apresentam baixa seleção (Figuras 19 e 20), evidenciando borda de bacia de sedimentação.

Analisando agora as superfícies de tendência do diāme tro mëdio, verificam-se clásticos mais grossos para a distribui ção areia (Figura 17), sugerindo novamente uma borda de bacia. $\vec{A}$ superfīcie de tendência do diāmetro mēdio da distribuição total (Figura 16), mostra por sua vez uma diminuição do diâmetro médio (em $\mathrm{mm}$ ), o que ē justificado pelo fato da superfície de tendên cia de teores de argila (Figura 22), apresentar os maiores való res para esta região. A argila teria origem provavelmente das rochas bäsicas.

A baixa relação clāsticos grossos/clásticos finos (Figu ra 18), estā tambēm ligada ao fato desta ärea ser extremamente rica em argila.

Como evidencia suplementar de borda de bacia de sedimen tação apontam-se os altos valores no mapa de tendência do nümero de classes texturais (Figura 21).

\section{4 .3 - Fonte a SE do mapa}

A ārea prōxima apresenta clāsticos mais grossos, tanto na distribuição total (Figura 16) como na distribuição areia 
(Figura 17). Apresenta ainda altos valores na relação de clästi cos grossos/clästicos finos (Figura 18), combaixos valores de porcentagem de argila (Figura 22) e altos valores do número de classes texturais (Figura 21), evidenciando borda de bacia de se dimentação.

Por outro lado as superficies de tendéncia dos valores de seleção para a distribuição total (Figura 19) e principalmen te para a distribuição areia (Figura 20), mostram um aumento da seleção em direção à ärea fonte. 0 fato se explica pela boa se leção verificada na ārea fonte (Formação Botucatu). Os altos va lores de seleção estão ligados a características herdadas dos sedimentos preexistentes.

\section{4 .4 - Área a SW do mapa}

As superfícies de tendēncia de todos os parāmetros gra nulomētricos evidenciam esta ārea como o centro deposicional da bacia.

0 mapa de tendēncia de seleção da distribuição total (Fí gura 19), mostra mā seleção nesta ārea, o que se justifica pelos altos teores de argila (Figura 22). 
CAPITULO 6

CARACTERIZAÇÃO SEDIMENTOLOGGICA DAS FĀCIES DA FORMAÇÃO BAURU

As observações de campo e laboratōrio deste trabalho permitem a aplicação do termo Formação Bauru, dividido em trēs fäcies: Fācies A (inferior), Fācies B (intermediäria) a qual en globa os arenitos tufāceos da região Uberaba e Fácies C (superior). Acredita-se assim, que os arenitos tufáceos da "Formação" Uberaba pertençam à Formação Bauru (Quadro I e Figura 23).

6.1 - OBSERVAÇð̃ES DE CAMPO

As observações de campo sugerem certas caracteristicas sedimentares variāveis na Formação Bauru.

6.1 .1 - Expressão morfolōgica

A unidade superior (Fácies C) apresenta-se com topografia mais movimentada (escarpas sustentadas por arenitos com nīveis de nódulos carbonáticos), desniveis de cerca de 100 metros e drenagem formando vales profundos e estreitos. Nas unida des inferiores (Fācies A e B) a topografia é mais suave, caracterizada por pequenas colinas de flancos pouco inclinados e des níveis não superiores a 50 metros. A drenagem forma vales abertos e poucos profundos. 
QUADRO 1 - ANRLLISE, COMPARATIVA: DAS UNI DADES DA: FORMAĢO BAURU

\begin{tabular}{|c|c|c|c|c|}
\hline & \\
\hline & & FACIES A & FACIES B & FACIES C \\
\hline \multirow{4}{*}{ 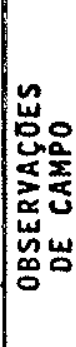 } & Expressão morfolögtca & Topografta suave & Topografia suave & Topografia movimentada \\
\hline & Nödulos carbonāticos & Poucos, esparsos ou ausentes & $\begin{array}{l}\text { Esparsos ou formando pequenos } \\
\text { nfveis }\end{array}$ & $\begin{array}{l}\text { Numerosos e concentrados } \\
\text { em niveis }\end{array}$ \\
\hline & Pelotas de argila & Raras ou ausentes & Raras ou ausentes & $\begin{array}{l}\text { Numerosas esparsas ou } \\
\text { formando niveis conglome } \\
\text { räticos }\end{array}$ \\
\hline & Calcärios & Ausentes & Ausentes & Presentes \\
\hline \multirow{7}{*}{ 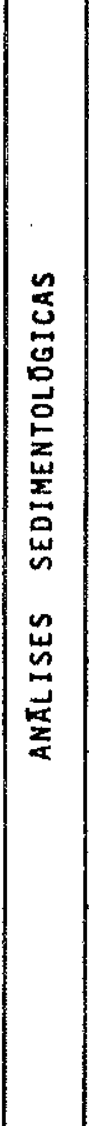 } & Calcimetria & $\begin{array}{l}\text { Teores de } \mathrm{CaCO}_{3} \text { de } 0 \text { a } 10 \% \text {, } \\
\text { no arenito }\end{array}$ & $\begin{array}{l}\text { Teores de } \mathrm{CaCO}_{3} \text { de } \mathrm{O} \text { a } 10 \% \text {, } \\
\text { no arentito }\end{array}$ & $\begin{array}{l}\text { Teores de } \mathrm{CaCO}_{3} \text { de } 0 \text { a } \\
10 \% \text {, no arenito }\end{array}$ \\
\hline & $\begin{array}{l}\text { Parāmetros estatistst- } \\
\text { cos da distribuigãoo } \\
\text { arefa }\end{array}$ & $\begin{array}{l}\text { Apresenta diâmetro mëdlo do } \\
\text { intervalo areia variando de } \\
\text { areia fina a muito fina } \\
\text { A seleção do intervalo arela } \\
\text { varia entre bem a moderada-. } \\
\text { mente selecionada }\end{array}$ & $\begin{array}{l}\text { Apresenta diâmetro médio do } \\
\text { intervalo areia variando de } \\
\text { areia fina a mutto fina } \\
\text { A selecão do intervalo arefa } \\
\text { êmoderadamente selecionada }\end{array}$ & $\begin{array}{l}\text { Apresenta diāmetro médio } \\
\text { do intervalo areja varian } \\
\text { do de areia média a areiá } \\
\text { fina } \\
\text { A seleção do intervalo } \\
\text { areia e moderadamente se- } \\
\text { lecionada }\end{array}$ \\
\hline & $\begin{array}{l}\text { Teor de stlte mats } \\
\text { argila }\end{array}$ & $\begin{array}{l}\text { Muito variāvefis (5. a } 50 \% \text { ) com } \\
\text { teor medio em torno de } 25 \%\end{array}$ & $\begin{array}{l}\text { Mufto variāvets (0 a } 50 \%) \text { com } \\
\text { teor medio em torno de } 25 \%\end{array}$ & $\begin{array}{l}\text { Variação de } 5 \text { a } 30 \% \text {, com } \\
\text { teor medio em torno de } 15 \%\end{array}$ \\
\hline & $\begin{array}{l}\text { Assemblēias mineralō } \\
\text { gicas (pesados) }\end{array}$ & $\begin{array}{l}\text { Mut to homogenea. Predominañ- } \\
\text { cta de augita. Granada subor } \\
\text { dinada }\end{array}$ & $\begin{array}{l}\text { Augita, turmalina, zircão,gra } \\
\text { nada, epidoto, hornblenda, pe } \\
\text { wskita predominantes }\end{array}$ & $\begin{array}{l}\text { Epidoto, turmalina, grana } \\
\text { da, zircáo, rutiog, augi } \\
\text { ta e estaurolita, predomi } \\
\text { nantes }\end{array}$ \\
\hline & $\begin{array}{l}\text { Nūmero de espécies mit } \\
\text { neralögicas (pesados) }\end{array}$ & 2 a 3 & 6 a 8 & 6 a 8 \\
\hline & $\begin{array}{l}\text { Indices de maturidade } \\
\text { mineralogica (pesados) }\end{array}$ & $\begin{array}{l}\text { ZTR igual a } 0 \text { e } I_{2}, I_{3} \text { e } I_{4} \\
\text { com valores altos e constan } \\
\text { tes }\end{array}$ & $\begin{array}{l}\text { ZTR variāvel }(0 \text { a } 60 \%) \text { e } I_{2}, \\
I_{3} \text { e } I_{4} \text { com valores extrema- } \\
\text { mente variävets }\end{array}$ & $\begin{array}{l}\text { ZTR variävel }(10 \text { a } 80 \%) \text { e } \\
1_{2}, \mathrm{I}_{3} \text {, e } \mathrm{I}_{4} \text { com valores } \\
\text { extremamente variäveis }\end{array}$ \\
\hline & Areas fontes & $\begin{array}{l}\text { Rochas bãsfcas (auglta) e } \\
\text { secundariamente rochas meta } \\
\text { morficas (granada) }\end{array}$ & $\begin{array}{l}\text { Diversificadas; bäsicas-alca } \\
\text { linas(perowskita),basaltos } \\
\text { (augitatmetamorficas (grana- } \\
\text { da e eptoto) sedimentos pre } \\
\text { existentes(zircão e turmali= } \\
\text { na arredondadas) }\end{array}$ & $\begin{array}{l}\text { Diversificadas; metamörfi- } \\
\text { cas (granada e epidoto), se } \\
\text { dimentos preexistentes (izir } \\
\text { cano turmalina e rutilo ar } \\
\text { redondados) basal tos (augi } \\
\text { tas) }\end{array}$ \\
\hline
\end{tabular}




\section{1 .2 - Nódulos carbonáticos}

A unidade superior (Fácies C) apresenta frequentemente nódulos carbonāticos esparsos e niveis de concentração de nödulos. Nas unidades inferiores os nödulos são esparsos ou formando pequenos niveis ( $F \bar{a} c i e s$ ), ou ainda, raros e mesmo ausentes ( $F \underline{a}$ cies $A$ ).

\section{1 .3 - Pelotas de argila}

A unidade superior da Formação Bauru (Fācies C) é rica em pelotas de argilas esparsas, e frequentemente formando niveis conglomeräticos. Nas unidades inferiores (Fäcies $A$ e B) as pelotas de argila são raras ou ausentes.

\section{1 .4 - Calcärios}

A unidade superior apresenta calcārios, como exemplifi cado em Ponte Alta (MG) e Agudos (SP), enquanto as unidades infé riores (Fācies $A$ e $B$ ) são isentas de horizontes de calcārios.

\section{2 - ANÄLISES SEDIMENTOLŌGICAS}

Analisando os perfis das sondagens de General Salgado (Fäcies $A$ e $B$ ) e Alvinlāndia (Fācies $C$ ), verificam-se as seguintes características nas trēs unidades da Formação Bauru. 


\subsection{1 - Calcimetria}

Os teores de carbonato de cālcio como cimento nos are nitos da Formação Bauru variam de 0 a $10 \%$ e não obedecem a qual quer padrão.

6.2.2 - Parâmetros estatísticos da distribuição areia (Figuras 24 e 25)

6.2.2.1 - Diâmetro médio

Apesar do intervalo areia das amostras da Formação Bau ru apresentar um diāmetro mëdio muito homogēneo, verifica-se que as unidades inferiores (Fācies $A$ e $B$ ) são mais finas (diāmetro mëdio entre areia fina e areia muito fina) que a unidade superior (diâmetro mëdio entre areia mëdia e areia fina).

$6.2 .2 .2-\operatorname{Seleção~}$

A unidade intermediāria (Fácies $B$, com intervalo areia variando de bem a moderadamente selecionado), apresenta-se melhor selecionada que as unidades superior e inferior (Fácies $A$ e $C$, com intervalo areia moderadamente selecionado).

\section{2 .3 - Teor de silte + argila (Figuras 24 e 25)}

Apesar da grande variação de teores de silte + argila das amostras, verifica-se que a unidade superior(Fācies C) apre senta menores valores do que as unidades inferiores (Fäcies $A$ e B). 


\subsection{4 - Assembléia de minerais pesados}

Fäcies A: caracteriza-se por apresentar uma assemblēia muito homogēnea, mostrando predomināncia total de augitas e secundariamente granadas (Figuras 28 e 29 ).

Fācies B: apresenta uma assembléia composta principal mente de augitas, turmalinas, zircões, granadas, epidotos, horn blendas e perowskitas (Figuras 28 e 29 ).

Fācies $C$ : apresenta uma assemblēia composta principal mente de epidotos, turmalinas, granadas, zircões, rutilos, augi tas e estaurolitas (Figuras 26 e 27 ).

A Fācies A caracteriza-se pela alta frequéncia em augitas.

A Fäcies $B$ se diferencia das demais pela presença de perowskitas.

6.2 .5 - Nümero de espécies mineralógicas (Figuras 30 e 31)

Fācies A: apresenta pequeno nümero de espécies minera lógicas (2 a 3 espëcies).

Fācies B: apresenta grande nūmero de espēcies minera lögicas (em torno de 6 a 8 espécies).

Fäcies C: apresenta grande nümero de espécies (em torno de 6 a 8 espécies).

6.2.6 - Indices de maturidade mineralógica(Figuras 32 e 33)

Fäcies $A$ : apresenta $I_{1}(Z T R=z i r c a ̃ o+t u r m a l i n a+r \underline{u}$ 

tilo) igual a zero, e os indices $\mathrm{I}_{2}, \mathrm{I}_{3}$ e $\mathrm{I}_{4}$ com valores altos
e constantes.

Fäcies B: apresenta I, (ZTR) com valores muito variāveis (de 0 a $60 \%$ ), e os outros indices com valores extremamente variāveis.

Fācies C: apresenta $I_{1}$ (ZTR) com valores muito variāveis (de 10 a $80 \%$ ), e os outros indices com valores extremamen te variāveis.

A Fäcies A se identifica das demais por apresentar I, (ZTR) igual a zero, e os outros indices com valores altos constantes.

\subsection{7 - Áreas-fonte}

Fācies A: contribuição predominante de rochas bāsicas (augitas) e secundariamente rochas metamörficas (granadas).

Fācies B: sugere fontes diversas; rochas bāsicas a ul trabāsicas alcalinas (perowskita), basalto (augita), metamörficas (granada e epĩdoto) e sedimentos preexistentes (turmalinas e zircões arredondados). A esta fācies pertencem os arenitos tu fáceos da região de Uberaba.

Segundo HASUI (1968) - "De modo geral, a contribuição de detritos resuitantes da erosão de rochas vulcānicas preexistentes na Formação Uberaba, decresce para o topo, sem contudo deixar-se suplantar por detritos de outras origens. 0 enriqueci mento de detritos não vulcanögenos com o tempo parece relacionar-se com a disponibilidade crescente de fontes adequadas,exumadas gradativamente, à medida que a cobertura vulcānica era re movida".

Segundo HASUI (1968) - "Contribuição direta da atividade vulcánica dos focos alcalinos do oeste mineiro foi admitida atē a presente data. Todavia, a geocronologia mostra que os värios distritos do oeste mineiro são da mesma fase (HASUI \& 
CORDANI, 1968) e a observação de campo mostra ser ela bem anterior à deposição da Formação Uberaba. As rochas da Formação Ube raba são epiclāsticas, na classificação de FISHER (1961)".

Fäcies $c$ : indica fontes diversificadas, metamörficas (granada e epĩdoto), sedimentos preexistentes (zircão, turmalina e rutilo arredondados) e basaltos (augita).

A Fäcies $A$ se caracteriza pela predomināncia de rochas bāsicas como äreas-fonte, enquanto as outras unidades apre sentam āreas-fonte muito diversificadas.

A Fācies $B$ se destaca das demais pela contribuição de rochas bāsicas a ultrabāsicas alcalinas. 


\section{CAPITULO 7}

ESTRATIGRAFIA DA FORMAÇĀO BAURU

7.1 - TRABALHOS PREVIOS

ALMEIDA \& BARBOSA (1953) dividiram a Formação Bauru no Estado de São Paulo em duas unidades, denominando a inferior de Itaqueri e a superior de Marília. De acordo com a descrição litolögica dada a estas unidades pelos autores supra citados, parece que a cimentação carbonātica dos arenitos seria característica fundamental da unidade superior que a distingue da infe rior, não carbonātica.

FREITAS (1955) usou o nome "Sērie Bauru" como sinōnimo de Formação Bauru, admitindo uma subdivisão estratigräfica em dois membros (Membro Itaqueri e Membro Bauru). O Membro Itaqueri, basal, seria constituido por conglomerados fluviais, com expressão geográfica em ārea, bem caracterizado e separado frequentemente do membro superior por discordāncia erosiva. 0 Membro Bauru, superior, seria caracterizado por arenitos com estru turas gradativas frequentes passando, localmente no sentido lateral ou vertical, para litofácies argilosa ou conglomerātica.

BARBOSA et al.(1970) admitem, na ārea norte de Uberaba, a Formação Bauru constituĩda, de baixo para cima, pela făcies Uberaba, Ponte Alta e Bauru.

HASUI (1968) admitiu a existência de uma disconformidade (discordancia paralela) entre a Formação Bauru e a Formação Uberaba. Este fato estā associado ao carāter mais amplamente transgressivo da Formação Bauru e a presença de um conglomerado basal no contato com a Formação Uberaba. Em virtude desta discordância o mesmo autor sugeriu adotar o nome Formação Ubera ba e não Fácies Uberaba. 
GROSSI SAD et aZ. (1971) e HASUI \& SADOWSKI

abandonam a denominação Fācies Ponte Alta usando em seu lugar o nome Fácies Itaqueri.

LADEIRA et al. (1971) aceitam a subdivisão sugerida por BARBOSA et al. (1970), enquanto maior nūmero de informações estratigrāficas não se fizeram disponiveis para que o problema se resolva de maneira mais definitiva.

SUGUIO (1973b) usa o termo Formação Bauru, reunindo a Fācies Itaqueri ou Ponte Alta e Fäcies Bauru, e dando autonomia à Formação Uberaba, como unidade litoestratigrāfica independente da Formação Bauru de acordo com idēia anterior de HASUI (1968).

SOARES \& LANDIM (1975) subdividiram a Formação Bauru em cinco fäcies, sendo as três inferiores (fäcies de arenitos finos, fácies de arenitos argilosos e fäcies de arenitos sīlticos) pertencentes à Formação Bauru Inferior e as duas fäcies superiores (fäcies de arenitos tufäceos e fäcies calco-conglome rātica) pertencentes à Formação Bauru Superior.

\section{2 - DISCUSSÃO FINAL}

A presente pesquisa suporta as conclusões de BARBOSA et al. (1970) que consideram os sedimentos tufäceos (tufos e ar gilitos cineriticos), associados a conglomerados, uma fäcies da Formação Bauru. Neste trabalho entretanto não se utilizou o nome Fācies Uberaba, pois seus sedimentos pertencem à Fäcies B, de extensão regional muito maior, embora com caracteristicas local mente tufáceas (contribuição local de rochas vulcānicas).

Com toda a probabilidade as fäcies superiores ( $B$ e $C$ ) do Bauru são unidades transgressivas. Na região de Uberaba, a Fäcies B representada pelos tufitos da "Formação Uberaba" estā diretamente sobre o basalto, faltando a Fācies Inferior (A). 
$\bar{e}$ a unidade onde encontram restos de dinossauros e outros rēpteis. Deve ela corresponder à Fäcies $C$. Os restos fösseis se en contram de fato, predominantemente, nesta fäcies e em parte no topo da fäcies B (incluindo pequenos restos de répteis nos arenitos tufáceos da região de Uberaba). A Fācies $C$ engloba a Formação Marĩlia de ALMEIDA \& BARBOSA (1953), a Fācies Ponte Alta e os arenitos superiores (Fácies Bauru) de BARBOSA et al. (1970).

As duas ocorrēncias de calcārios da Formação Bauru, Uberaba (MG) e Agudos (SP), foram interpretadas como se situando a primeira na base e a segunda no topo da formação.

Dentro de um quadro de sedimentação tão homogênea quanto a da Formação Bauru, seria difícil entender porque, na região de Uberaba, o calcārio deva se sedimentar na base e na região de Agudos, no topo, Mas analisando-se estratigraficamente a Formação, verifica-se que os calcärios se situam realmente na Fäcies $C$. Acontece que na região de Uberaba não se encontra a Fācies A (Inferior) e a Fācies Intermediāria (B) ē representa da pelos tufitos da "Formação Uberaba". De fato, o calcārio se encontra na base, mas na base da Fācies superior (C).

As trēs fäcies inferiores que constituem a Formação Bauru Inferior de SOARES \& LANDIM (1975), devem corresponder a uma ünica, a qual, neste trabalho, é denominada Fācies A (Inferior).

A fäcies de arenitos tufāceos que corresponde à Fācies Uberaba de BARBOSA et al. (1970), aparece no trabalho de SOARES \& LANDIM (1975), na posição estratigräfica que se acredi ta correta, mas no presente trabalho engloba-se os arenitos tufāceos na Fācies $B$ (Intermediāria), de extensão regional muito ma is ampla.

A fácies calco-conglomerātica de SOARES \& LANDIM(1975) corresponde grosseiramente à fäcies C (Superior).

Segundo MEZZALIRA (1974) - "Os conglomerados basais encontrados nos testemunhos de sondagem, nos diversos pontos da bacia, são litologicamente diferentes dos encontrados nos aflo ramentos que a literatura refere como pertencentes ao Bauru. 
Nos testemunhos predominam seixos de basaltos e nos afloramentos, os de quartzo e quartzitos".

Neste trabalho exprime-se a opinião de que os afloramentos de conglomerados com seixos de quartzo e quartzitos, são de borda de bacia (Fäcies $B$ elou C), onde há forte contribuição de rochas igneas e metamörficas prē-cambrianas. Jä os conglomera dos com seixos de basalto encontrados em subsuperficie se situariam mais para o interior da bacia onde deve ter predominado a contribuição basāltica (Fācies $A$ ).

A Formação Caiuá não foi objeto de estudo neste trabaTho. Sua posição estratigräfica ē duvidosa, e no mapa incluso foi considerada de idade Cenozóica, embora se coloque dūvidas so bre esta idade. 0 autor acredita inclusive, que a Formação Caiuă pode ser estratigraficamente inferior à Formação Bauru, ou até correlacionāvel à Fācies A (Inferior) da Formação Bauru. 
CAPITULO 8

\section{CONCLUSOES PRINCIPAIS}

a - Analisando as variações de teores de carbonato de cālcio como cimento dos arenitos da Formação Bauru dos poços de Alvinlāndia e General Salgado, verifica-se que não hä uma varia ção sistemātica, fato jā anteriormente observado por FREITAS (1955), MEZZALIRA (1974) e PIERUCETI \& MAX BRANDT (1974).

b - Acredita-se não ser vāilido o uso do teor de carbo nato em cimento de arenitos da Formação Bauru, como um critério estratigräfico. Por outro lado as observações de campo e labora tōrio levam a concluir que um importante critērio estratigräfico para a Formação Bauru ē a ocorrēncia de nōdulos carbonāticos.

c - o carbonato de cālcio é em parte autígeno, proveniente de alterações intra-estratais de augitas.

d - As amostras da Formação Bauru apresentam grande homogeneidade litológica, sendo constituỉda principalmente de arenitos finos a muito finos, argilosos e/ou carbonāticos muito pobremente a pobremente selecionados, com assimetria variando de muito positiva a positiva, com curtose muito leptocürtica a platicūrtica, exibindo de 9 a 10 classes texturais.

e - Comparando as frequencias relativas dos minerais pesados transparentes não micāceos nas duas frações granulomētricas estudadas, verifica-se que alguns minerais; como zircão, rutilo, anatásio, perowskita e apatita, apresentam frequéncias relativas mais altas na fração $0,125-0,062 \mathrm{~mm}$, enquanto turma lina, granada, augita, estaurolita e cianita apresentam frequēn cias mais altas na fração $0,250-0,125 \mathrm{~mm}$.

$f$ - A mistura de minerais instāveis e estāveis permite classificar o sedimento como mineralogicamente imaturo. Esta imaturidade parece estar ligada a condições de clima semi-ärido durante a sedimentação. 
Acredita-se que o clima da Formação Bauru foi ūmido al ternado com fases secas (ARID, 1973) no inĩcio da sedimentação e para o topo as fases secas se tornaram mais frequentes e mais rigorosas.

g - As superfícies de tendēncia dos parāmetros granulo métricos das amostras da Formação Bauru, evidenciam uma bacia simples, onde superficies de 39 grau apresentam coeficientes de correlação acima de $70 \%$.

h - A partir das superfīcies de tendencia dos parâmetros granulomētricos, dos indices de maturidade mineralögica e de frequências de minerais pesados, verifica-se a existēncia de três fontes principais na contribuição dos sedimentos da Formação Bauru.

A fonte a $\underline{N W}, \bar{e}$ formada de sedimentos preexistentes.

Fonte a $\underline{N E}$, è constituīda de rochas bäsicas do Grupo São Bento, metamörficas dos Grupos Araxā e Canastra e alcalinas do Triāngulo Mineiro.

Fonte a $\underline{S E}$ formada de sedimentos preexistentes.

$i$ - A partir do estudo integrado das observações de campo e estudos sedimentológicos em laboratório (calcimetria, anālise granulométrica e minerais pesados), a Formação Bauru pode ser dividida em trēs unidades (Fäcies $A, B$ e $C$ ).

A Fācies A (Inferior) provēm fundamentalmente da erosão de rochas bāsicas da Formação Serra Geral do Grupo são Bento, com uma contribuição secundāria de rochas metamōrficas (xistos).

A Fäcies B (Intermediāria) e C (Superior) provēm de fontes diversificadas, com contribuição de rochas metamōrficas, retrabalhamento de sedimentos paleo-mesozóicos da Bacia do Paranā e rochas bāsicas da Formação Serra Geral.

A Fācies $B$ apresenta como peculiaridade a contribuição de rochas bāsicas-ultrabāsicas alcalinas, pertencentes ao evento magmātico alcalino que afetou o Triānguro Mineiro no Mesozóico, e localmente de rochas alcalinas do Estado de São Paulo. 
A realização deste trabalho tornou-se possĩvel graças à colaboração prestada ao longo das diferentes etapas do seu desenvolvimento.

Queremos externar os nossos sinceros agradecimentos ao Professor Doutor Setembrino Petri, pela orientação e estimulo que imprimiu a esta pesquisa.

Ao Professor Doutor Josē Moacyr Vianna Coutinho, um agradecimento especial, por ter em diferentes etapas franqueado seus préstimos e conhecimentos.

Aos Professores Doutores Gilberto Amaral, Kenitiro Suguio e Vicente José Fülfaro; e aos colegas Benjamin Bley de Brito Neves, Max Brandt Neto e Toshie Yamaguishi pelas valiosas crí ticas e sugestões.

Aos estagiārios do Laboratōrio de Sedimentologia do Instituto de Geociencias da Universidade de São Paulo, Ana Maria Gōes e Jorge Kazuo Yamamoto, pela efetiva colaboração prestada, nas diferentes fases das anālises sedimentológicas, e pelos deba tes promovidos nas suas interpretações.

A Senhora Nair de Campos Louzada e ao Senhor Josē Ponchirolli, pelos trabalhos de datilografia; ao Senhor Jayme Alves da Silva e equipe,pelos trabalhos gräficos; a Srta.Itacy Kroehne e ao Senhor Pedro Gennari Filho, pela confecção dos desenhos.

E ao pessoal técnico e administrativo do Instituto de Geociēncias da Universidade de São Paulo, que direta ou indireta mente colaborou com o autor. A todas essas pessoas o autor consigna o seu profundo reconhecimento. 
ALLEN, P. \& KRUMBEIN, W.C. - 1962 - Secondary trend components in the top Ashdown pebble bed, a case history -J.Geol., v. 70, pp 507-508

ALMEIDA,F.F.M.de \& BARBOSA,0. - 1953 - Geologia das Quadrículas de Piracicaba e de Rio Claro, Estado de São Paulo - DNPM-DGM, 143, Rio de Janeiro

ARID,F.M. - 1973 - o comportamento espacial da Formação Bauru na região norte-ocidental do Estado de São Paulo Rev.Bras. de Geociēncias, v.3, nọ 1, 23-35, São Paulo BARBOSA,0.; BRAUN,0.P.G.; DYER,R.C. \& CUNHA,C.A.R. - 1970 -Geo logia da região do Triāngulo Mineiro - DNPM-DFPM,Bol. $136,140 \mathrm{p}$, Rio de Janeiro

COUTINHO,J.M.V. \& COIMBRA,A.M. - 1974 - Os pesados do Barreiras na Costa Oriental Brasileira - Anais do XXVIII Congr.Bras.Geol.Soc.Bras.Geol., Porto Alegre (no pre10)

FREITAS,R.0.de - 1955 - Sedimentação, estratigrafia e tectónica da Série Bauru (Estado de São Paulo) - Bol. da Faculdade de Filosofia, Ciēncias e Letras da USP, no 194, Geologia 14, $185 \mathrm{p}$, São Paulo

FULFARO,V.J. - 1971 - A evolução tectōnica e paleogeogrāfica da Bacia Sedimentar do Paranā pelo "Trend Surface Analysis" - Escola de Engenharia de São Carlos da USP,Geol. no $14,112 \mathrm{p}$

FULFARO,V.J. \& AMARAL, G. - 1970 - "Trend Surface Analysis" das areias da praia do Tenōrio, Ubatuba, SP - Anais XXIV Congr.Bras.Geol. Soc.Bras.Geol., 299-305, Brasilia

GROSSI SAD, J.H.; CARDOSO,R.N. \& COSTA,M.T.da - 1971 - Formações Cretācicas em Minas Gerais: uma revisão - Rev. Bras. Geociēncias, São Paulo, 1 (1) - 2-21

HARBAUGH,J.W. \& MERRIAN,D.F. - 1968 - Computer application in stratigraphic analysis - John Wiley \& Sons, $257 \mathrm{p}, \mathrm{N}$. York 
HASUI,Y. - 1968 - A Formação Uberaba - Anais XXII Congr. Bras. Geo1. Soc.Bras.Geol., 167-179, Belo Horizonte, MG

HASUI, Y. - 1969 - 0 Cretäceo do oeste mineiro - Bol.Soc. Bras. Geol., $18(1), 39-56$

HASUI,Y. \& SADOWSKY,G.R. - 1972 - Membro Itaqueri e Fäcies Ponte Alta, Resumo das Comunicações da XXIV Reunião da SBPC, 24 (6), 138, São Paulo

HOWARTH,R.J. - 1967 - Trend-Surface fitting to random data An experimental test. Am.Jour. Sci., 265, 619-625

HUBERT,J.F. - 1962 - A zircon-tourmaline-rutile maturity index and the interdependence of the composition of heavy mineral assemblages with the gross composition and texture of sandstones - J.Sed.Petrol., 32, 440450

HUBERT,J.F. - 1971 - Analysis of heavy-mineral assemblages. (in Carver R.E. "Procedures in sedimentary petrology") - Wiley-Interscience, N.York

INSTITUTO BRASILEIRO DE GEOGRAFIA E ESTATISTICA - 1972 - Carta do Brasil ao mịlionēsimo. Folhas de Goiānia, Rio de Janeiro, Paranapanema e Belo Horizonte

INSTITUTO GEOGRAFICO E GEOLOGICO - 1974 - Mapa Geolōgico do Estado de São Paulo. Escala 1:1.000.000 - São Paulo

KRUMBEIN,W.C. \& GRAYBILL,F.A. - 1965 - An introduction to sta tistical models in geology - McGraw-Hill Book Co. $412 \mathrm{p}$

KRUMBEIN,W.C. \& SLOSS,L.L. - 1963 - Stratigraphy and Sedimentation, $2 \underline{a}$ ed., W.H.Freeman and Co., $660 \mathrm{p}$

LADEIRA,E.A. et al. - 1971 - o Cretāceo em Minas Gerais - Mesa Redonda do XXV Congr.Bras. de Geol. - Anais do Congr.Bras.Geol. Soc.Bras.Geol., v.1, 15-31, São Pau 10

MADUREIRA FILHO,J.B.de; VALARELLI,J.V.\& GOMES,C.B. - 1976 - No va ocorrência de rochas alcalinas no Estado de São Paulo (em preparação)

MEZZALIRA,S. - 1974 - Contribuição ao conhecimento da estrati grafia e paleontologia do Arenito Bauru - Bol.do Instituto Geogräfico e Geolögico,no51, 163 p.,São Paulo 
MINISTERIO DAS MINAS E ENERGIA : Mapa Geolögico do Brasil -1971DNPM/DGM, Escala 1:5.000.000, Rio de Janeiro

PETTIJOHN,F.J. - 1957 - Sedimentary rocks - Harper \& Brother N.York, 2a edt., $718 \mathrm{p}$

PIERUCETI,J.A. \& BRANDT NETO,M. - 1974 - Comportamento do cimento calcārio da Formação Bauru na região de São Josē do Rio Preto - Anais do XXVIII Congr.Bras.de Geol., Porto Alegre (no prelo)

SETZER,J. - 1948 - Algumas contribuições geolögicas dos estudos dos solos realizados no Estado de São Paulo - Rev. Bras. Geografia, Rio de Janeiro, 10 (1), 41-104, ilust.

SOARES,P.C. \& LANDIM,P.M.B. - 1975 - Comparison between the tectonic evolution of the intracratonic and marginal basins in South Brazil. International Symposium on Continental Margins of Atlantic Type, São Paulo (no prelo)

SUGUIO,K. - 1973a - Introdução à Sedimentologia - Editōra Blucher - Editōra da Univ.de São Paulo, 317 p, São Paulo

SUGUI0,K. - 1973b - A Formação Bauru: Calcārios e sedimentos de tríticos associados (2 volumes) - Tese de Livre Docēncia, Instituto de Geociēncias da USP, $236 \mathrm{p}$, (inēdita)

SUGUIO,K.; COIMBRA,A.M. \& GUARDADO,L.R. - 1974 - Correlação sedimentológica de arenitos da Bacia do Paranā - Bol. IG, Instituto de Geociēncias, USP, 4, 85-116, São Paulo

SUGUIO,K.; BERENHOLC,M. \& SALATI,E. - 1975 - Composição quĩmica e isotópica dos calcārios e ambiente de sedimentação da Formação Bauru - Bol. IG, Instituto de Geociēncias,USP, 6 ,55-75, São Paulo 